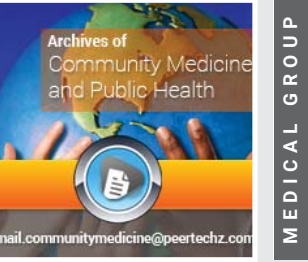

\section{nCOVID-19: Its diagnosis, possible preventive measures, therapeutic interventions and}

\section{management}

\author{
Mrinal Kanti Poddar* and Apala Chakraborty \\ Department of Pharmaceutical Technology, Jadavpur University, 188, Raja S. C. Mallick Road, \\ Kolkata-700032, India
}

Received: 15 June, 2020

Accepted: 06 July, 2020

Published: 08 July, 2020

*Corresponding author: Prof. Mrinal Kanti Poddar, Department of Pharmaceutical Technology, Jadavpur University, 188, Raja S. C. Mallick Road Kolkata-700032, India, Tel: +91-33-2442-2490; E-mail:mrinalkp@yahoo.com

Keywords: Diagnosis; Immune function; nCOVID-19; Respiratory virus; SARS-CoV2; Therapeutic interventions; Vaccines

https://www.peertechz.com

\section{Check for updates}

\begin{abstract}
Novel coronavirus (nCOVID-19) is a current global threat causing severe infections to millions of people throughout the world. WHO has reported in their case-based surveillance that the aged and male populations are most vulnerable to this recent coronavirus infection. This disease-causing virus, named as SARS-CoV-2, is a respiratory coronavirus that probably originated from the bat with a substantially different genetic makeup concerning the other known coronaviruses. Structurally SARS-CoV- 2 is a diverse single-stranded RNA virus having spike (S) glycoprotein in its envelop that is associated with the transmission of the virus by binding with the host target receptor. The principal target site of nCOVID-19 is angiotensin-converting enzyme 2 (ACE2) in the host receptor. The expression of ACE2 target site varies according to the genetic susceptibility and $\mathrm{ABO}$ blood group locus causing variation in the severity of the infection. The virus usually affects the inflammatory pathways, responsible for white blood cell activation and clot formation after interacting with pathogen pattern recognition receptors. The major pathological symptoms of severe nCOVID-19 are mild to severe respiratory and bowel syndromes. Prevention of infections has been achieved by social distancing depending on the concept of aerosolized/droplet transmission of virus and by maintaining personal hygiene. Remedies like ayurvedic, homeopathic, micronutrients such as vitamins and minerals along with regular physical exercises like yoga and meditation are also found to be helpful in disease prevention. The treatments that have been applied so far with some positive responses are antimalarial chloroquine and hydroxychloroquine, antivirals, plasma therapy, steroids, omega-3-fatty acid derivatives, vitamin $\mathrm{C}$ infusion, etc. Some global healthcare bodies are also in action for the development of vaccines therapy against nCOVID-19. Apart from the infection control, some other associated issues like long term social distancing, constant stress, anxiety, change in lifestyle are affecting adversely the aged populations and also the other part of the society. There is no doubt that government bodies from various countries throughout the world are taking extreme measures to control and mitigate the pandemic, but this untoward situation is still far from the control of human races and supposes to take more time and further scientific interventions and management are needed to be continued.
\end{abstract}

\section{Abbreviation}

ACE2: Angiotensin-Converting Enzyme 2; ADCC: AntibodyDependent Cellular Cytotoxicity; ARDS: Acute Respiratory Distress Syndrome; B cells: Bursa cells; CD4+ T cells: Cluster of Differentiation 4+ Thymus cells; CD8 $+\mathrm{T}$ cells: Cluster of Differentiation 8+ Thymus Cells; CDC: ComplementDependent Cytotoxicity; CFT: Complement Fixation Test; CI: Confidence Interval; CNS: Central Nervous System; CoV HKU4: Tylonycteris bat coronavirus HKU4; CRS: Cytokine Release Syndrome; cryo-EM: cryo-Electron Microscopy; CSF: Cerebro Spinal Fluid; CT: Computerized Tomography; DFA: Direct Fluorescent Assay; DIC: Disseminated Intravascular Coagulation; E: Envelope protein; EC50: half maximal Effective
Concentration; EIA: Enzyme-Immunoassay; ELISA: EnzymeLinked Immunosorbent Assay; FP: Fusion Peptide; GS-5734: Remdesivir; GSK: GlaxoSmithKline; HCoV-229E: Human Coronavirus 229E; HCoV-HKU1: Human Coronavirus HKU1; HCoV-NL63: Human Coronavirus NL63; HCoVOC43: Human Coronavirus OC43; HI, Hemagglutination Inhibition; HR1: Heptad Repeat 1; HR2: Heptad Repeat 2; HyFc: Hybridoma Fusion; IBD: Inflammatory Bowel Diseases; IC: Intracellular domain; IFA: Immuno- Fluorescence Assay; IFN- $\gamma$ : Interferon gamma; IgD: Immunoglobulin $\mathrm{D}$; IgG4: Immunoglobulin G4; IL1beta: Interleukin-1 beta; IL-6: Interleukin-6; IL7: Interleukin-7; INO-4800: DNA vaccine for SARS-COV-2; IQR: Interquartile Range; kb: kilo byte; LAMP: Loop Mediated Isothermal Amplification; LAT: Lateral-Flow Test; LFIA: 
Lateral-Flow Immune chromatographic assay; mAbs: monoclonal antibodies; MERS-CoV: Middle East Respiratory Syndrome Coronavirus; mRNA-1273: Lipid Nanoparticle (LNP)-encapsulated mRNA-based vaccine; N: Nucleocapsid protein; nCOVID-19: novel Corona Virus Disease-2019; NIAID: National Institute of Allergy and Infectious Diseases; NK cells: Natural Killer; NKG2A: Natural Killer cell G2A; nM: nano Molar; nsp14: nonstructural protein 14; NTD: N-Terminal Domain; Orf1a,b: Open reading frame $1 \mathrm{a}$ and b 226; PCR: Polymerase Chain Reaction; PD: Peptidase Domain; RA: Rheumatoid Arthritis; RBD: Receptor-Binding Domain; RBD: ReceptorBinding Domain; RBM: Receptor-Binding Motif; RdRP: RNAdependent RNA Polymerase; RNA: Ribonucleic Acid; rRTPCR: Real-Time reverse transcription-Polymerase Chain Reaction; RSV: Respiratory Syncytial Virus; RTLAMP: Reverse Transcription Loop-Mediated Isothermal Amplification; RTPCR: Reverse Transcription Polymerase Chain Reaction; SARSCoV-2: Severe Acute Respiratory Syndrome Coronavirus 2; SD1: Subdomain 1; SD2: Subdomain 2; SLE: Systemic Lupus Erythematosus; T-705: Favipiravir; T-cell: Thymus cell; TM Transmembrane region; TMPRSS2: Transmembrane Protease Serine 2; TNF-alpha: Tumor Necrosis Factor-alpha; WHO: World Health Organization

\section{Introduction}

The novel coronavirus, nCOVID-19, also named as severe acute respiratory syndrome coronavirus 2 (SARS-CoV-2), is a zoonotic virus causing mild respiratory tract infections to unusual fatal pneumonia in humans upon exposure [1]. In the recent past, the deadly infection due to nCOVID-19 has been first identified in Wuhan City, China on $29^{\text {th }}$ December 2019 and rapidly takes a shape of a global pandemic by increasing exponentially during the last 7 months [2]. WHO has reported (as mentioned in the report released on $28^{\text {th }}$ May 2020) that there are more than 10.1 million nCOVID-19 positive cases globally with almost 0.5 million deaths [3]. WHO has also claimed, based on their case-based surveillance that the occurrence of infection is age and gender-based (Figure 1). As per their report, the ratio of the rate of infection in males and females is 1.03:1 with a median age of 51 years (i.e. interquartile

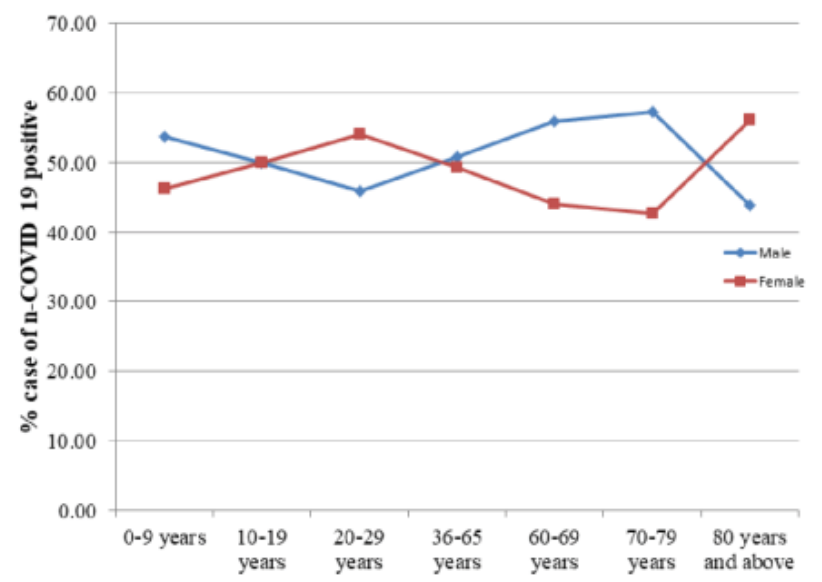

range, IQR: 36-65 years) [4]. The most common symptoms of the nCOVID-19 positive patients are mild to moderate in nature like nasal secretions, cough, fever, dyspnea, myalgia, and occasionally diarrhea [5]. Around $17 \%$ of the cases are developing acute respiratory distress syndrome (ARDS), among which $65 \%$ cases are deteriorated to the extent of septic shock and/or multiple organ failure [5]. It is also evident that patients with underlying medical conditions such as cardiovascular diseases, diabetes mellitus, renal failure, respiratory diseases are more susceptible to nCOVID-19 infections [6,7]. So far, symptomatic therapies along with some nonspecific antiviral therapies have been tried as a therapeutic regimen of nCOVID-19 positive cases as the development of nCOVID-19 specific therapies (including vaccines) are still under clinical trials and yet to be available for the treatment purpose.

The ongoing worldwide investigations on nCOVID-19 have highlighted many insights into this infection like viral structure, immunopathology, associated symptoms, diagnostic approaches, possible preventive measures, and control, etc. The impacts of this pandemic over the global socio-economic condition, mental health of the society, etc., have also been studied [8]. In this context, it may be mentioned that social distancing, long term lockdown, discontinuation of personal work routine, the constant fear of the infection, concern for family and friends, fear of losing financial independence are collectively affecting badly the mental health of a large section of the population [8]. This leads to an increase in the level of stress followed by anxiety, depression, sleeplessness, and more chances to expose in the diseased conditions [9]. Many misconceptions and unauthentic information related to nCOVID-19 are circulating in the social media platform which causing more panic among the masses [10]. In this review, the characteristics of nCOVID-19, its possible diagnosis preventions, therapeutic interventions, and management have been discussed in detail based on the recent investigations going on worldwide. This summarized yet informative content of the review article will help to get an overall impact on the idea of the entire status of this ongoing nCOVID-19 pandemic at a glance which will help the mass to get a clear cut knowledge about this current pandemic in our belief.

\section{Respiratory viruses}

Some major viral pathogens such as influenza virus, rhinovirus, adenovirus, respiratory syncytial virus (RSV), and coronavirus are responsible for maximum cases of morbidity and mortality due to the development of acute respiratory diseases (ARD) [11,12]. The clinical manifestations of respiratory infections generally help to characterize the pathogens such as rhinovirus can be characterized by typical common cold and RVS by bronchiolitis [13]. But the common viral respiratory syndromes are often associated with more than one viral infection which is presented in Table 1.

\section{Coronavirus}

As described in Table 1, Coronavirus is a class of respiratory viruses belongs to the coronaviridae family. The main vector of this virus is the bat and the infections occur to the human

Citation: Poddar MK, Chakraborty A (2020) nCOVID-19: Its diagnosis, possible preventive measures, therapeutic interventions and management. Arch Community Med Public Health 6(2): 115-129. DOI: https://dx.doi.org/10.17352/2455-5479.000090 
Table 1: Respiratory virus and their associated syndromes.

\begin{tabular}{|c|c|c|c|c|}
\hline $\begin{array}{l}\text { Type of } \\
\text { Respiratory } \\
\text { viruses }\end{array}$ & Genus & Symptoms & Diagnostic tools & References \\
\hline \multirow{2}{*}{ Influenza virus } & \multirow{2}{*}{$\begin{array}{c}\text { Influenza virus A, } \\
\mathrm{B}, \mathrm{C} \text {, and D \& } \\
\text { Orthomyxoviridae family, } \\
\text { Isavirus, Quaranjavirus and } \\
\text { Thogotovirus genus }\end{array}$} & $\begin{array}{l}\text { Major symptoms: } \\
\text { Influenza-like illness, } \\
\text { pneumonia, cough. }\end{array}$ & \multirow{2}{*}{$\begin{array}{l}\text { Viral culture; IFA; } \\
\text { DNA-microarraybased, sequencingbased } \\
\text { tests, ELISA, PCR. }\end{array}$} & \multirow{2}{*}[14-17]{} \\
\hline & & $\begin{array}{l}\text { Minor symptoms: } \\
\text { common cold, } \\
\text { bronchiolitis. }\end{array}$ & & \\
\hline \multirow[b]{2}{*}{ Adenovirus } & \multirow{2}{*}{$\begin{array}{l}\text { Adenoviridae family, } \\
\text { Atadenovirus, } \\
\text { Aviadenovirus, } \\
\text { Mastadenovirus and } \\
\text { Siadenovirus genus }\end{array}$} & $\begin{array}{l}\text { Major symptoms: } \\
\text { Pneumonia. }\end{array}$ & \multirow{2}{*}{$\begin{array}{l}\text { Viral culture; Indirect } \\
\text { ELISA; IFA; LAT; } \\
\text { EIA; Real-time } \\
\text { PCR based }\end{array}$} & \multirow[b]{2}{*}[18-21]{} \\
\hline & & $\begin{array}{l}\text { Minor symptoms: } \\
\text { Influenza-like } \\
\text { illness, common cold, } \\
\text { bronchiolitis. }\end{array}$ & & \\
\hline \multirow{2}{*}{ Coronavirus } & \multirow{2}{*}{$\begin{array}{c}\text { Coronaviridae family \& } \\
\text { coronavirus (alpha, } \\
\text { beta, delta and gamma genus) }\end{array}$} & $\begin{array}{l}\text { Major symptoms: } \\
\text { Common cold. }\end{array}$ & \multirow{2}{*}{ RT-PCR; rRT-PCR ; RT-LAMP } & \multirow{2}{*}[22-25]{} \\
\hline & & $\begin{array}{l}\text { Minor symptoms: } \\
\text { Pneumonia. }\end{array}$ & & \\
\hline \multirow[b]{2}{*}{ Rhinovirus } & \multirow{2}{*}{$\begin{array}{l}\text { Picornaviridae family \& } \\
\text { Enterovirus genus }\end{array}$} & $\begin{array}{l}\text { Major symptoms: } \\
\text { common cold. }\end{array}$ & \multirow{2}{*}{$\begin{array}{l}\text { CFT; HI; IFA; } \\
\text { ELISA; Semi-nested RT-PCR assay; One step } \\
\text { Panenterhino /Ge/o8 real-time RTRCR assay; }\end{array}$} & \multirow[b]{2}{*}[26-28]{} \\
\hline & & $\begin{array}{l}\text { Minor symptoms: } \\
\text { Pneumonia, } \\
\text { bronchiolitis. }\end{array}$ & & \\
\hline \multirow[t]{2}{*}{ Human RSV } & \multirow{2}{*}{$\begin{array}{l}\text { Paramyxoviridae family \& } \\
\text { Pneumovirus genus }\end{array}$} & $\begin{array}{l}\text { Major symptoms: } \\
\text { Bronchiolitis, } \\
\text { pneumonia; }\end{array}$ & \multirow{2}{*}{$\begin{array}{c}\text { IFA; ELISA-based test; DFA; LFIA (Remel } \\
\text { Xpect, Binax } \\
\text { Now RSV, BD } \\
\text { Directigen EZ RSV, QuickLab RSV, Respi- } \\
\text { Strip); real-time PCR. }\end{array}$} & \multirow[t]{2}{*}[29-31]{} \\
\hline & & $\begin{array}{l}\text { Minor symptoms: } \\
\text { Common cold, cough. }\end{array}$ & & \\
\hline
\end{tabular}

Abbreviations: CFT: Complement Fixation Test; DFA: Direct Fluorescent Assay; EIA: Enzyme-Immunoassay; ELISA: Enzymelinked Immunosorbent Assay; HI: Hemagglutination inhibition; IFA: Immunofluorescence assay; LAMP: Loop-mediated isothermal amplification; LAT: Lateral-Flow Test; LFIA: Lateral-Flow Immunochromatographic Assay; PCR: polymerase Chain Reaction; RT-PCR: Reverse Transcription-Polymerase Chain Reaction; rRT-PCR: Real-Tme Reverse Transcription-polymerase chain reaction; RT-LAMP: Reverse Transcription Loop-Mediated Isothermal Amplification.

by various other cross-species such as avians, rodents, and chiropets [32,33]. Earlier six subtypes of human coronaviruses have been identified as follows: HCoV-HKU1, HCoV229E, HCoVOC43, HCoV-NL63, severe acute respiratory syndrome coronavirus (SARS-CoV), and middle east respiratory syndrome coronavirus (MERS-CoV) [34].

In 2002, SARS-CoV, the novel human Coronavirus, has been first recognized as a cause of atypical pneumonia mostly in older adults and a probable cause of epidemic which affects around 8000 humans worldwide after originating from Guangdong Province, China [35]. SARS-CoV is a subclass of Zoonotic virus having horseshoe bats as reservoir hosts [36]. The important traits of SARS-CoV are (a) potentially high RNA mutation rates $\left(2 \times 10^{-6}\right)$ in contrast to other RNA viruses and also being able to encode $3^{\prime \prime}-5^{\text {"e }}$ exonuclease RNA proof-reading activity within nonstructural protein 14 (nsp14) [37,38], (b) coronavirus family frequently recombinant between genomes and subgenomic replication complexes during mixed infections [39] and (c) being a larger sized RNA virus (27-31 kb), coronavirus can change or modify as they have numerous open reading frames towards the 3' end of the genome and shows the characteristics of rapid adaptation to the novel hosts [37].

MERS-CoV infection, causing respiratory disease in humans, has been reported first in June 2012 [40]. Human
MERS-CoV is a $30 \mathrm{~kb}$ positive single standard RNA genome that closely resembles to lineage $\mathrm{C} \beta$-coronaviruses of Tylonycteris bat $\mathrm{CoV}$ HKU4 and also with the MERS-CoV derived from camels with whom it has $>99.5 \%$ identical nucleotides $[41,42]$. MERS-CoV infection has been reported to cause around 851 deaths in 27 countries due to a lack of commercial vaccines and therapeutic interventions as reported by WHO until September 2019 [43].

\section{The new virus SARS-CoV-2}

The new coronavirus isolated in January 2020 is SARSCoV-2, a diverse single-stranded RNA, probably originated from the bat with a substantially different genetic sequence concerning the other known coronaviruses [44,45]. Unlike SARS which has a shorter incubation period of 1-4 days, nCOVID-19 has a latency of up to 14 days under which the virus can infect an average of 3.77 numbers of other people [44,46]. The infection mechanism is dependent on the envelope spike (S) glycoprotein which facilitates receptor binding, membrane fusion, host tropism as well as transmission power of the virus [45]. This trimeric S protein cleaved in S1 and S2 subunit during viral infections [47]. S1 consists of the receptor-binding domain (RBD) and S2 is responsible for membrane fusion. S1 directly binds to the peptidase domain (PD) of angiotensinconverting enzyme 2 (ACE2) in the host receptor and host 
protease cleaved the $\mathrm{S} 2$ cleavage site and initiate the critical process of viral infections [47-49]. In recent research, it has been established that the ectodomain of the $\mathrm{S}$ glycoprotein of SARS-CoV-2 binds with the PD of ACE2 with a dissociation constant (Kd) of 15nM [50]. ACE2 in human physiology is a type I membrane protein expressed in the lungs, heart, kidneys, and intestine which helps in the maturation of peptide hormone angiotensin that controls the vasoconstriction and blood pressure $[51,52]$. The reported cryoelectron microscopy (cryo-EM) structures suggest that two S proteins of SARSCoV-2 trimers can simultaneously bind to an ACE2 homodimer [53]. This binding of S protein of SARS-CoV-2 with ACE2 is 10to 20-fold greater in attraction than with S protein of SARS$\mathrm{CoV}$ virus, which may be a reason behind the rapid human to human transmission worldwide [54,55]. In this context, it may be mentioned that this ACE2 expression rate is higher in less effected X-heterozygous females compared to males, as the ACE2 gene lays on the $\mathrm{X}$-chromosome. Further, several genes involved with inflammation and immune response ( $\mathrm{ABO}$ locus, SRY, SOX3, ADAM17) are also located on the X-chromosomes and directly or indirectly plays an impact on the ACE1/ACE2 balance. Rebalancing of this ACE1/ACE2 ratio or higher level of ACE2 might reduce the inflammation, thrombosis, and death related to nCOVID-19 [56]. The monoclonal antibodies (mAbs) S230, m396, and 80R showing cross-reactivity with SARS-CoV RBD have no possible binding affinity towards SARS-CoV-2 RBD despite the structural homology between SARS-CoV and SARS-CoV-2 [50]. It may further suggest that SARS-directed mAbs will not necessarily cross-reactive with SARS-CoV-2 and this information will help in antibody isolation and therapeutic design for SARS-CoV-2 [50]. It is also evident that SARSCoV-2 employs transmembrane protease serine 2 (TMPRSS2) for $\mathrm{S}$ protein priming. S protein priming by TMPRSS2 is found to be essential for the entry of the virus into the target cells as well as the spreading of infections [57-59]. Like many other infectious diseases such as influenza $A$ viruses and coronaviruses, this TMPRSS2 is the critical factor for spreading of SARS-CoV-2 and thus a convenient drug target to combat SARS-CoV-2 [57-62]. In this context, it may be mentioned that camostat mesylate a serine protease inhibitor has blocking

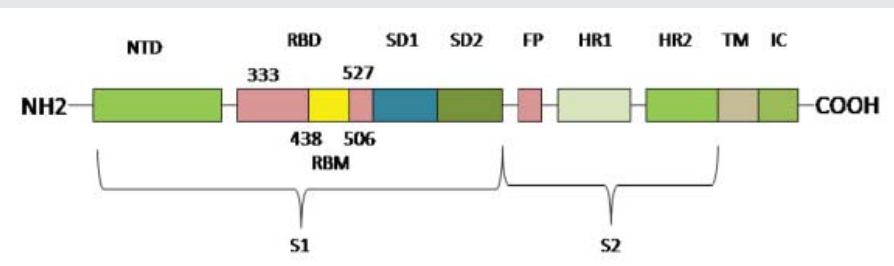

Figure 2: Topology of SARS-CoV-2 spike monomer.

The probable structure SARS-CoV-2 has been depicted by Lan J et al. (2020).

The figure has been taken from Lan J et al. (2020) Nature, https://doi.org/10.1038/ s41586-020-2180-5 [63]. FP, fusion peptide. HR1, heptad repeat 1. HR2, heptad repeat 2. IC, intracellular domain, NTD, N-terminal domain. RBD, receptor-binding domain. RBM, receptor-binding motif. SD1, subdomain 1. SD2, subdomain 2. TM, transmembrane region.

activity against TMPRSS2 $[57,58]$.

\section{Structural elucidation of the receptor-binding domain of SARS-CoV-2}

The X-ray crystallographic study of SARS-CoV-2 RBD as demonstrated by Lan, et al. (2020) has shown loops forming core along with short connecting helices with twisted fivestranded antiparallel $\beta$ sheet $(\beta 1, \beta 2, \beta 3, \beta 4$, and $\beta 7$ ) [60-63]. An extended insertion formed with short $\beta 5$ and $\beta 6$ strands, $\alpha 4$ and $\alpha 5$ helices and loops forms receptor-binding motif (RBM) is the main contacting residues for ACE2 binding. The $\beta$ sheet structure is stabilized by three pairs of a cysteine residue. This extended concave outer surface in RBM of SARS-CoV-2 RBD gets an attachment to the bottom side of the N-terminal helix ACE2 small lobe Figure 2.

\section{Immunopathology of nCOVID-19}

The SARS-CoV-2-induced immune responses are occurred in two phases [64]. During the first phase of incubation, the specific adaptive immune response gets activated to eliminate the virus and to mitigate the disease progression [64]. The development of this endogenous protective immune response during the early phase solely depends on the health of the patients and the immune-boosting approaches are helpful in this phase only. In this context, it may be mentioned that genetic differences are strong contributors to the variation in the immune response to pathogens in individuals [64]. A recent investigation of Ellinghaus, et al., (2020) have shown a 3p21.31 gene cluster as a genetic susceptibility locus for the nCOVID-19 patients as a reason for respiratory failure. The ABO blood group system has a potential involvement in this risk as locus 9q34.2 coincided with the ABO blood group locus. The study further revealed that blood group A has a higher and blood group $\mathrm{O}$ has lower chances of respiratory failure during nCOVID-19 infection in comparison to the other groups [65]. Impairment of immune response initiates the viral attack to the high ACE2 expressed organs such as intestine and kidney. In the second phase of the disease, cytokine release syndrome (CRS) or increased level of pro-inflammatory macrophages and granulocytes are observed followed by inflammation of lungs, respiratory distress, and associated disorders in severe stage [66]. Lagunas-Rangel and Chávez-Valencia (2020) have reported that severe nCOVID-19 patients have higher IL-6/ IFN $-\gamma$ ratio than moderate nCOVID-19 patients which could be the possible reason behind the cytokine storm followed by lung damage [67]. Cytokine storm syndrome is a resultant effect of excessive release of pro-inflammatory stimuli and/ or deregulation of inflammation due to host-derived or environmental causes and associated with severe systemic inflammation, hemodynamic instability, multiple organ failure, and finally death [68]. These proinflammatory stimuli are superantigens (causing massive activation of $\mathrm{T}$-cell receptors), antigens, toll-like receptor (TLR) ligands, allergens, or proinflammatory cytokines [68]. The lack of capacity to induce an immune response in the patient of SARS-CoV-2 may be the reason behind the remaining or returning of viruses after the complete cure of the patients [67]. In severe nCOVID-19 patients, lymphocytopenia is also observed with a significant reduction in B cells, natural killer (NK) cells, $\mathrm{CD}_{4}+\mathrm{T}$ cells, and CD8+ T cells, monocytes, eosinophils and basophils along with an increase in neutrophil count $[66,69,70]$. The upregulation of exhaustion markers such as NKG2A on cytotoxic lymphocytes (such as NK, CD8+ T cells) is observed in nCOVID-19 positive

Citation: Poddar MK, Chakraborty A (2020) nCOVID-19: Its diagnosis, possible preventive measures, therapeutic interventions and management. Arch Community Med Public Health 6(2): 115-129. DOI: https://dx.doi.org/10.17352/2455-5479.000090 
patients [71-74]. SARS-CoV-2-specific antibodies have been detected from the plasma of convalescent patients and used to treat SARS-CoV-2 positive with acute respiratory distress syndrome (ARDS) patients [75]. Another pathological condition of nCOVID-19 is thrombocytopenia which has been observed in $36.2 \%$ of cases of severe nCOVID-19 positive cases and also carrying the risk of developing disseminated intravascular coagulation (DIC) [76-78]. It has been reported as per the International Society on Thrombosis and Haemostasis diagnostic criteria that DIC has been observed in 15 out of 21 non-survivors of the nCOVID-19 patients [79]. Some other reports have shown by a meta-analysis that the presence of thrombocytopenia increases the chance of severe diseases up to five folds whereas in severe disease the platelet counts decrease (mean difference: $-31 \times 10^{9} / \mathrm{L}, 95 \%$ CI: -35 to $-29 \times 10^{9} /$ L) [80]. The occurrence of thrombocytopenia and elevated D-dimer are probably due to the over activation of coagulation cascade and platelets as the procoagulant and anticoagulant homeostatic mechanisms get disrupted during viral infections [81]. This phenomenon also involves endothelial dysfunction, Toll-like receptor activation, von Willebrand factor elevation, and tissue-factor pathway activation $[80,81]$. It is also known that platelets, the key mediator of inflammatory pathways, are responsible for white blood cell activation and clot formation after interacting with pathogen pattern recognition receptors or immunoglobulin Fc receptors and complement receptors (pathogen recognition) [82]. Disruption of this mechanism has a major role in viral infections associated procoagulant effect $[82,83]$. One rare pathological condition of nCOVID-19 is viral encephalitis which has been found in one nCOVID-19 infected patient in Beijing, China. The study with cerebrospinal fluid (CSF) of nCOVID-19 infected patients has revealed the presence of SARS-Cov-2 in the central nervous system (CNS) and showing the symptoms of encephalitis [84].

\section{Symptoms of nCOVID-19}

The nCOVID-19 is mainly transmitted through the respiratory droplets from coughing and sneezing and the common symptoms are fever and respiratory symptoms like cough and dyspnoea, and also there is evidence of bilateral atypical pneumonia during infections. It has also been observed that aerosolized SARS-CoV-2 particles remain for hours in the air and are able to transport over a usual distance (6 feet) like outside of rooms and intra building [85]. WHO has also reported the existence of this virus in stools of the patient in $30 \%$ cases which persist up to 4-5 weeks, although not known whether it signifies the presence of an infectious virus or not $[2,86,87]$. It has been found that nCOVID-19 also present in the glandular cells of the rectum along with interstitial edema and lymphoblasts-cytosis, although their association with pathological evidence such as diarrhea during nCOVID-19 infection has not been clear yet $[2,88]$. The increased level of proinflammatory cytokines (IL-1B, TNFalpha) has an association with inflammatory bowel diseases (IBD), characterized by fever, abdominal pain, and diarrhea, during relapse and remission phases of nCOVID-19 [86,89]. Zhang, et al. (2020) have investigated by using single-cell transcriptomic analysis that the digestive system is also a potential route of SARS-CoV-2 infections along with the respiratory tract [90]. Zhang, et al. have also suggested that this may be a possible reason behind symptomatic diarrhea as an enteric symptom of nCOVID-19 as the sites of enterocytes are highly expressed with ACE2 and TMPRSS2 [89]. The rare case of nCOVID19 associated encephalitis has shown meningeal irritation signs in the patients along with low WBC count $(3.3 \times$ $\left.10^{9} / \mathrm{L}\right)$ and lymphopenia $\left(0.8 \times 10^{9} / \mathrm{L}\right)$ [91].

\section{Diagnosis of nCOVID-19}

Globally, RT-PCR is recognized as an only validated tool for the confirmation of nCOVID19 cases to verify the asymptomatic cases (those who have been in close contacts of nCOVID-19 positive cases) and also to differentiate nCOVID-19 from the other respiratory infections [92-94]. As suggested by WHO, various RT-PCR protocols are examining the amplification of nCOVID-19 specific genes i.e. (a) envelope protein (E); (b) RNA-dependent RNA polymerase (RdRP); (c) open reading frame 1a and b 226 (Orf1a,b) ; (d) nucleocapsid protein; (N) genes of SARS-CoV-2; or (e) combination of those genes (two or more), for screening and identification of nCOVID-19 positive cases. At least one of these genes should be detected by RT-PCR for interpreting the result as positive as per the guideline of WHO [94-98]. At present, the knowledge regarding nCOVID-19 is not fully proved, so it has been recommended to collect the specimen from the upper respiratory tract (Nasopharyngeal swab, oropharyngeal swab, nasopharyngeal aspirates, etc.) and also from the lower respiratory tract (Sputum, bronchial washing, tracheal aspirates, transtracheal aspirates, bronchoalveolar lavage, transbronchial lung biopsy, etc.) within seven days of symptoms onset [99]. Reports are available regarding the possibilities of transmission of nCOVID-19 via the fecal-oral route [100-102]. SARS-CoV-2 viral nucleotide detection has been found to be positive in anal swabs but negative in nasopharyngeal swabs even after 42 days of infections suggesting the requirement of resting the fecal specimen of the nCOVID-19 patients also [103].

Due to the shortage of laboratory-based molecular testing capacity and reagents, diagnostic test manufacturers are now more focused on manufacturing easy to use devices to expedite the testing process in less time [104]. The test kits are mainly able to detect (a) viral protein fraction from the human respiratory sample or (b) human antibodies generated in response to infection. For the detection of the target antigen, the testing kit usually contains specific antibodies fixed paper strip or plastic casing that can give visual signal upon antigenantibody reactions [104]. The testing process usually takes 30 mints of time and the accuracy rates varying from $38 \%$ to $80 \%$ in different kits $[104,105]$. The testing is only able to detect in acute or early infection time when the target antigens are present in sufficient concentration [104]. The limitation of such a test is the specificity of antibodies towards nCOVID-19 antigen as antibodies on the test strip may also be able to recognize the human coronavirus that causes the common cold. In that case, the test should be performed only in those patients whose symptoms are very likely to nCOVID-19. Due to this reason WHO has not recommended these types of antigendetecting rapid diagnostic tests for patient care. The other

Citation: Poddar MK, Chakraborty A (2020) nCOVID-19: Its diagnosis, possible preventive measures, therapeutic interventions and management. Arch Community Med 
kind of readily available test kit can detect the virus-specific antibody in the blood or plasma of the patient $[106,107]$. Several studies have suggested that antibody response develops only in the second week of infection, which means detection of the infection by antibody response is possible in the recovery phase and may not be effective enough to control the transmission or implementing clinical interventions for therapy [106,108-110]. Chances of cross-reaction are still possible and may produce false-positive results that is why WHO has not recommended this type of test for patient care so far $[104,111,112]$.

\section{Preventive measures for nCOVID-19}

1. National Health Commission of the People ${ }^{e e s}$ Republic of China has recommended the following precautionary measures for the infected patients according to the different phase of nCOVID-19 infections [113,114].

(a) During the initial days of infections, suspected patients may be considered for home isolation with routine health check-ups if the symptoms of the patient are mild. These classes of patients should be treated with antiviral or other recommended drugs for symptomatic relief in the initial stage to prevent further deterioration of health. $[114,115]$.

(b) Patients with worst symptoms such as aged patients and those with other medical issues should be treated with more care and repetitive assessment based on routine chest CT scan of the infected individuals [113].

(c) If in some patients, after 10 days, any expansion of lung damage or acute cardiovascular diseases persists with an increase in inflammatory responses, then the necessary treatments are required to control immune modulation [113].

(d) More progression in infection would become more difficult for critically ill patients to tolerate and in that phase, the mortality rates become high/maximum [113].

2. Guidelines, as mentioned below, are needed to be followed as precautionary/ preventive measures by the patients and the persons who are in close contact with the patient (Persons who are suspected of nCOVID-19 exposure) as recommended by several authorities:

(a) Advised to take 14 days of self-quarantine from the day of exposure $[115,116]$

(b) Medical attention to be taken, if any kind of fever or coughing, shortness of breath, or diarrhea observed during this period [115].

(c) Surveillance is needed for the persons who have been exposed at a low-level to the suspected or nCOVID-19 positive patients [116]

\section{Preventive measures recommended for travelers:}

(a) Routine precautions should be taken before entering and leaving the nCOVID-19 affected zones [117].
Table 2: Home remedies and precautions for early prevention of nCOVID-19.

1. Regular drinking of warm water.

2. Minimum 30 minutes practice of yoga and meditation.

3. Daily administration of natural immune boosters like turmeric, cumin, coriander, and garlic, etc.

4. Drinking of herbal tea with basil, cinnamon, black pepper, dry ginger, raisin once or twice a day.

5. Consumption of milk with turmeric powder.

6. Application of sesame oil, coconut oil, or ghee in both the nostrils twice a day (in morning and evening).

7. Inhalation of steam with mint leaves or caraway seeds.

8. Application of clove powder with honey in a sore throat or cough.

9. Practicing the oil pulling therapy by swishing 1 tablespoon sesame or coconut oil in the mouth for 2 to 3 minutes and then rinsing the mouth with warm water for once or twice a

10. Naturopathic nutrition (balanced diet with fruits and vegetables) is important for improving innate immunity, especially in comorbid patients.

11. Intermittent fasting or lemon juice fasting helped in boosting the immune system; reduce oxidative stress as well as may improve autophagy in comorbid patients.

The above information are taken from Ayush, Indian Council of Medical Research, Government of India [118].

(b) Frequently washing the hands especially after being in contact with affected persons [117].

(c) Avoidance of contact with dead farming animals or wild animals [117].

Recently the Government of India has published a list of home remedies and precautions for early prevention of nCOVID-19 which is expected to be effective as precautionary measures against the viral contaminations (Table 2) [118]. The government of India has also recommended "Dinacharya" -daily regimes and "Ritucharya"-seasonal regimes for immune-boosting based on Ayurveda's extensive knowledge in relation to prevention, care and to maintain a healthy life [118]. However, the application of "Dinacharya and Ritucharya" with the preventions of nCOVID-19 needs further investigation [118

United nation and WHO both recommended yoga/ meditation to reduce disease-related anxiety or stress [119]. Yoga is also recommended as a preventive measure for infection control as it has been well proved that yoga can reduce the IL- 6 and TNF-alpha as well as decrease the IL-1beta showing an effective impact on populations at risk or already suffering from the diseases associated with inflammations, although the consistent and regular practice is essential for achieving effective results [120].

Another possible aspect is the homeopathic treatment for the prevention of nCOVID-19 infection. The Cuban government has already promoted proactively the use of homeopathic medicine as protection for elderly persons against nCOVID-19 infection [121]. Cuba successfully prevented the outbreak of Leptospirosis epidemic by using homeoprophylactic 
approaches (oral administration of highly diluted pathogens) in the year 2007 [122,123]. In January 2020, Govt. of India has recommended Arsenicum album $30 \mathrm{C}$ as a preventive measure [123]. Recently in Naiminath Homoeopathic Medical College, hospital and Research Centre, Agra, India, trials of homeopathic medicines on 100 nCOVID-19 patients have been initiated by providing a combination of Arsenicum Album 30, Bryonia Alba 30, Gelsemium, Antimonium Tartaricum and Crotalus Horridus, to the patient by Dr. Surabh Kumar with an expectation of preventing the transfer of asymptomatic symptoms of nCOVID-19 to the symptomatic condition [124].

Administration of micronutrients like vitamins, minerals, etc. can protect the respiratory tract as antioxidants are important factors to boost immune function during the nCOVID-19 pandemic [125]. Vitamins like A, C or E are a good source of anti-oxidants which helps to increase (a) T-cell subsets, (b) lymphocyte response to mitogen, (c) interleukin-2 production, (d) potential of the activity of the natural killer cell, and (d) response to influenza virus vaccine [126]. Vitamin $\mathrm{D}$, which is likely to synthesized less in the body during quarantine due to lack of exposure in sunlight, able to protect the respiratory tract by preserving tight junctions and also helps to decrease the level of pro-inflammatory cytokines followed by reducing the risk of cytokine storm leading to pneumonia [127]. It is also evident that zinc has the potential to inhibit severe acute respiratory syndrome (SARS) coronavirus RNAdependent RNA polymerase (RdRp) template binding [128].

\section{Therapeutic interventions of nCOVID-19}

The in-vitro activity and clinical applications of some drugs applied so far for the treatment of nCOVID-19 are summarized below although none of them has been claimed to mitigate this infectious disease:

Chloroquine and hydroxychloroquine: Chloroquine and hydroxychloroquine, the anti-malaria and anti-inflammatory drugs, are now in limelight as a potential therapy of nCOVID-19 [129]. The mechanism of action of chloroquine and hydroxychloroquine is the inhibition of glycosylation of host receptors, proteolytic processing, and endosomal acidification followed by blocking the viral entry inside the host body [130,131]. Two research groups have observed the antiviral efficacy of chloroquine and hydroxychloroquine against SARS-CoV in a high dose regimen showing a reduction in the exacerbation of pneumonia and reducing the disease course. The hydroxychloroquine, a derivative of chloroquine, has EC50 $14 \mu \mathrm{M}$ against SAR-CoV-2 which is much lower than the EC50 of chloroquine, i.e. 23.90 $\mu \mathrm{M}$ [132]. Long term administration in high dose (400mg/day orally for 5 days in case of hydroxychloroquine or $500 \mathrm{mg} /$ once or twice in a day orally for chloroquine) of these drugs are associated with several side-effects (in less than $10 \%$ cases) such as myopathy, arrhythmias such as ventricular tachycardia and torsades de pointes [133-135]. China has reported the successful application of chloroquine in the treatment of more than 100 nCOVID-19 patients with improved radiological findings but the report is not yet published in any peer-reviewed journals
[129]. Also, a nonrandomized French trial has published the report of 20 in the hydroxychloroquine group (receiving 200mg hydroxychloroquine by mount in every $8 \mathrm{hrs}$ ) and 16 in the control group and found positive results in treated group with virologic clearance at day 6 and even better result with concomitant use of azithromycin [136]. But the associated cytotoxicity of drugs cannot be avoided as very recently, Borba, et al. (2020) have mentioned that this effect of chloroquine or hydroxychloroquine is lethal for aged nCOVID-19 infected patients especially those who have the previous report of cardiac diseases and application of such drugs need randomized clinical trials before further applications [137]. The mixed report as obtained for chloroquine and hydroxychloroquine is not able to state the exact mechanism of action of these drugs on nCOVID-19 as it showed effectively in some patients and thus need further exploration of the scientific background of the drugs before drawing any positive or negative conclusion.

Antiretrovirals: Anti-HIV antiviral such as Lopinavir/ ritonavir is also active against other coronaviruses and act by inhibiting 3-chymotrypsin-like protease although no published literature is available regarding their activity against SARS-CoV-2 [138-140]. The report available so far are retrospective, nonrandomized cohort studies, and difficult to conclude $[141,142]$. The dosing regimen for nCOVID-19 for lopinavir/ritonavir as per the report of the National Health Commission and State Administration of Traditional Chinese Medicine (March 2020) and Chao, et al. (2020) is 400mg/10omg twice daily for up to 14 days [143]. The drugs have significant drug-drug interactions and adverse effects i.e. gastrointestinal distress such as nausea and diarrhea, hepatotoxicity, etc which creates limitations for their applications [144,145]. Similarly, other antiretrovirals like darunavir have shown anti-SARSCoV-2 activities in-vitro but their effects on humans are still under investigation $[140,144]$.

Antivirals other than antiretrovirals: Ribavirin is an RNA polymerase inhibitor and effective against other coronaviruses [129]. However, information related to its activity against SAR-CoV-2 is limited and so far only extrapolated from results against other coronaviruses [129]. A high dose of ribavirin or in combination therapies has shown in vitro activity against SARS-CoV but that is also associated with several side effects and toxicities such as hematologic and liver toxicity [146]. This substantial teratogenicity and toxicity is the limitation of Ribavirin as a potential therapeutics of nCOVID-19 [147]. Influenza-like symptoms have been treated with Oseltamivir like neuraminidase inhibitor but it has no in-vitro activity against SARS-CoV-2 [148]. So far none of the clinical trials have included oseltamivir as proposed therapeutic interventions [149]. Recently, China and Russia have approved umifenovir as a potential antiviral against SARS as this drug can target $S$ protein/ACE2 interaction and inhibit the membrane fusion of the viral envelope [150,151]. A nonrandomized clinical data has recently established that the use of umifenovir for a median duration of 9 days in nCOVID-19 patients shows a lower mortality rate and higher compared to those who not receiving this drug [152]. Anti Ebola virus drug remdesivir or GS-5734 is a monophosphate pro-drug which converted

Citation: Poddar MK, Chakraborty A (2020) nCOVID-19: Its diagnosis, possible preventive measures, therapeutic interventions and management. Arch Community Med 
into active $\mathrm{C}$-adenosine nucleoside triphosphate analog after metabolism, is now in limelight as a potential candidate for nCOVID-19 therapy due to its anti-RNA virus activities against coronaviridae and flaviviridae [153]. Similarly, another antiEbola analog favipiravir or T705, a purine nucleotide which after activation inhibits the RNA polymerase and halt the viral replication, has shown a broad activity against RNA viruses [154]. EC50 of favipiravir against SARS-CoV-2 is $61.88 \mu \mathrm{M} / \mathrm{L}$ in Vero E6 cells [155]. For the treatment of the SARS-CoV-2 higher range of dosing has been proposed such that the recommended loading dose is $2400 \mathrm{mg}$ to $3000 \mathrm{mg}$ every 12 hours/day followed by a maintenance dose of $1200 \mathrm{mg}$ to $1800 \mathrm{mg}$ every 12 hours per day considering its mild side-effects in comparison to other antiviral drugs [156]. Recently, India-based Glenmark Pharmaceuticals has got the regulatory approval in India for the manufacturing and marketing of favipiravir under the brand name FabiFlu for the treatment of mild to moderate nCOVID-19 infections. As per the data obtained by their phase III clinical trial, the company has claimed that favipiravir has shown promising results in mild to moderate nCOVID-19 in age groups of 20 to more than 90 years and provide rapid decrease in viral load within four days, along with quicker symptomatic relief [157].

Vaccines: Vaccines are a fundamental requirement for long term protection against infection outbreaks [158]. Various approaches have been taken for the development of vaccines for nCOVID-19 worldwide. The $\mathrm{S}$ glycoprotein is mainly responsible for the receptor binding of the host cell, so it is a good target for the development of host Recombinant Subunit Vaccine [159]. Recently, Clover Biopharmaceuticals, Chengdu, China, collaborated with GSK, Middlesex, UK, and have announced the pre-clinical testing of a recombinant subunit vaccine for nCOVID-19. The vaccine has been generated with native-like trimeric viral spike, similar to trimeric S protein (S-Trimer), by using a mammalian cell culture-based expression system $[160,161]$. The immune response of the vaccine has been improved by using GSK's adjuvant system to S Trimer and finally, the detection of antigen-specific neutralizing antibodies has been done in the sera of fully-recovered nCOVID-19 patients $[160,161]$. Subunit vaccine is also under development by the University of Queensland, Australia, as they are using a transformative technology "molecular lamp" which is a polypeptide that helps to stabilize a surface protein and improves antigen recognition proving a stronger immune response [162]. Other than the subunit vaccine, DNA vaccines can also be served by direct injection of plasmids encoding the antigens followed by a wide range of immune responses [163]. The DNA vaccine development is focused on the improvement of the efficacy by using electroporation to deliver plasmids [164]. Inovio Pharmaceuticals, Plymouth Meeting, PA, and Beijing Advaccine Biotechnology, Beijing, China are conducting pre-clinical trials for DNA vaccine (INO-4800) against nCOVID-19 [165]. INO-4800 activates $\mathrm{T}$ cells by delivering DNA plasmids with the spike protein of SARS-CoV-2 [166]. Intradermal application is also under investigation to produce therapeutic antibodies and activate immune cells. The phase I trial is initiated by Inovio Pharmaceuticals in the USA and
China with the help of the Coalition for Epidemic Preparedness Innovations (CEPI) body [167]. On the other side, Moderna, Inc., Cambridge, MA, in collaboration with the National Institute of Allergy and Infectious Diseases (NIAID), USA has started the phase I clinical trials for an in silico mRNA vaccine (mRNA1273) encoded with viral Spike(S) protein [168]. This mRNAbased vaccine contains mRNAs encoding the antigens having advantages of absence of genome integration causing improved immune responses followed by the rapid development of multimeric antigens [158,169]. Genexine Inc., Gyeonggido, Republic of Korea, is also developing an nCOVID-19 vaccine using Hyleukin-7 platform technology by fusion of interleukin-7(IL-7) to hyFc [170]. This fusion is designed to hybridize the flexible hinge structured IgD and an unexposed junction site IgG4 which increases the sustained action of Fc fusion proteins and prevents the antibody-dependent cellular cytotoxicity (ADCC) and complement-dependent cytotoxicity (CDC) $[170,171]$. Very recently AstraZeneca and the University of Oxford have conducted a phase III clinical trial (ISRCTN89951424) in Brazil to determine the safety, efficacy and immunogenicity of the non-replicating ChAdOx1 nCoV-19 vaccine. The single intervention of this vaccine will be followed by $1 \mathrm{~g}$ paracetamol every $6 \mathrm{~h}$ for a day. It is expected to get the trial outcome by July 2021 [172].

External respiratory support: Studies suggest that respiratory failure is the main reason behind nCOVID-19 death [173,174]. The patients with respiratory distress and/or hypoxemia transnasal high-flow oxygen, endotracheal intubation, and invasive mechanical ventilation should use the external respiratory support as and when necessary if standard oxygen therapy does not function properly. In severe cases, a fiberoptic bronchoscope may be required for high-density sputum suction or bronchoalveolar lavage for their relief [175].

Myocardial protection: Vasoactive drugs like norepinephrine or dopamine, dobutamine for increasing the systemic functions, creatine sodium phosphate, vitamin $\mathrm{C}$, coenzyme $\mathrm{Q}$ for avoiding comorbid myocardial injury during severe nCOVID-19 infections, conservative fluid treatment for fluid resuscitation and to improve oxygen supply to tissues are also sometimes needed to the patients in severe conditions $[176,177]$.

Artificial liver support therapy: Treatments like plasma replacement, blood adsorption, perfusion, artificial liver blood purification system should be carried out in the severe nCOVID-19 patients with excessive inflammatory responses and failure of the liver. It may help to reduce the level of excess cytokines [175].

Steroids: Low doses of glucocorticoids for the short term could be a possible therapy for excessive inflammatory responses, progressive worsening of oxygenation markers, and rapid progressive imaging. Glucocorticoids can be considered in severe nCOVID-19 cases to prevent the progression of ARDS [175].

Specialized pro-resolving lipid autacoid mediators (SPMs): Resolvins and other SPMs, derived from omega-3 fatty acids have a stimulatory effect on the macrophage-mediated clearance

Citation: Poddar MK, Chakraborty A (2020) nCOVID-19: Its diagnosis, possible preventive measures, therapeutic interventions and management. Arch Community Med 
of debris and also found to counteract the pro-inflammatory cytokine production by the process, inflammation resolution [178]. Thus, SPMs affect viruses in a very low dose (in nanogram level) without being an immunosuppressive. SPMs also promote various anti-viral B cell antibodies and lymphocytes, making it a potential candidate for the treatment of nCOVID-19 [178].

Nutritional supplements for gut microbiota: The intestinal barrier can be disrupted by the high inflammatory responses during nCOVID-19 infection-causing bacterial translocation and secondary infections [179]. This phenomenon further increases the lipopolysaccharides influx which takes part in the release of TNF $\alpha$, IL1 $\beta$, and IL-6, causing further exacerbation of systemic inflammation [180]. Gut and respiratory tract flora interact and it has been found that gut microbiota can reduce enteritis and ventilator-associated pneumonia [179,181]. Administration of probiotics, energy source(s), amino acid, and trace elements are thus essential for the nCOVID-19 patients for maintaining the equilibrium of the gut microflora [175].

Vitamin C infusion: Administration of Vitamin C (15g/ day, I.V. for 4 days) to the nCOVID-19 patients with sepsis-related ARDS may have reduced the rate of mortality as observed in 167 ICU patients in the USA [182]. Very recently, a clinical trial for the investigation of the effect of Vitamin $\mathrm{C}$ infusion to treat the nCOVID-19 infected pneumonia has been initiated in Wuhan, China [183]. A total of 140 patients are taken under the clinical trial and infusion of $24 \mathrm{~g}$ of vitamin C per day for 7 days has been applied for trial [183]. The study is most likely to be ended by the month of September 2020. The patients are assessed based on the requirement of ventilation, organ failure score, length of stay in ICU, and also the rate of 28 days mortality [183].

Treatment with the plasma of recovered patients: From the experience of SARS and MERS, it is evident that plasma of recovered patients can be effective as a treatment of nCOVID-19 $[184,185]$. This is currently under clinical trial but it is expected to be effective on severe nCOVID-19 cases before applying any non-specific antiviral drugs although a very dynamic evaluation is needed [186,187].

\section{nCOVID-19 and global mental health}

Although the prevalence of nCOVID-19 is uncertain in the community there is no doubt that older persons are at much higher risk than the younger generation especially those with comorbidity $[188,189]$. The primary prevention for the aged generation is social isolation which is highly associated with depression, cognitive damage, cardiovascular, and other aging-related diseases ultimately leading to an increased rate of mortality. It is a well-known fact that people with mental illness have a lower expectancy of life than the general population [190]. A large group of populations is psychologically venerable due to poor physical and mental health, impaired access to services, and losing control over day-to-day normal lives. A greater focus is needed for the mental health of society during this lockdown phase [191]. Otherwise, anxiety, panic- like mental issues will worsen the outbreak of nCOVID-19 among the public. Retrospective case studies have shown that severe nCOVID-19 patients are showing neurological disorders like cerebrovascular diseases, consciousness impairment, and skeletal muscle symptoms [192]. The uncertainty of infection, their growth rate, and the corresponding mortality, etc. create a psychological disturbance in the population [193]. Meng and his team have conducted a survey in china with a total of 1556 samples and have observed that $37.1 \%$ of the seniors are experiencing depression and anxiety due to nCOVID-19 [194]. Qiu and others have recently shown that aged individuals are more prompt to emotional reactions [192]. They have also found that aged women are experiencing more anxiety and depression than aged men. However, no significant difference between age segments (60-64 years, 65-69 years, 70-74 years, 75-79 years, and above 80 years) are observed by them. A good diet, exercise, and sleep are most important during the phase of heightened emotion along with that reaching out to others for mutual support where ever required are also needed. Ironically the nCOVID-19 infection control needs public health measures that harm mental health such as social isolation causing fear of infection, frustration, boredom, and anxiety, etc [195]. The India based survey on the younger generation has shown that $80 \%$ of the educated young generation is preoccupied with the thought of the pandemic situation and $12.5 \%$ are facing sleep difficulties, $37.8 \%$ are going through paranoia and $36.4 \%$ of the participants are in distressful condition [8]. Even the academicians and researchers are also going through the same stressful situation due to lack of access to the university and their respective professional fields of activities [196]. The only option is to withdraw the social isolation as soon as the infection is under control and enough treatment is available in the market.

\section{Conclusion}

The global threat of nCOVID-19 has declared as pandemic and the world is still fighting with a crisis and millions of lives are still under threat. The occurrence of infection is based on age and sex following a ratio of 1.03:1 in the chances of infection between males and females. The diverse singlestranded RNA virus SARS-CoV-2, showing severe respiratory and bowel syndromes, is responsible for impairment of immune response followed by cytokine release syndrome, and carrying the risk of disseminated intravascular coagulation. Prevention of the infections by social distancing depending on the concept of aerosolized/droplet transmission of virus and maintaining personal hygiene are most important to break the viral chain as there are no fully proven remedies available for this virus so far. Some remedies like ayurvedic, homeopathic, micronutrients such as vitamins and minerals along with regular physical exercises like yoga and meditation are also important for disease prevention. The treatments such as antimalarial chloroquine and hydroxychloroquine, antivirals plasma therapy, steroids, omega-3-fatty acid derivatives, etc. have been reported so far as a possible therapeutic regimen. So far no full proved antiviral treatment or vaccine is available for the treatment leaving control and prevention as the only option to deal with this deadly infection [197]. Not only heath,

Citation: Poddar MK, Chakraborty A (2020) nCOVID-19: Its diagnosis, possible preventive measures, therapeutic interventions and management. Arch Community Med 
but this global pandemic also has a huge impact over, social, economic, cultural as well as psychological damages [198]. One thing that cannot be ignored is the chances of the reoccurrence of this disease condition soon after nCOVID-19 with the same or some other infections and therefore, control is needed from every part of the society. It is important to understand and reorganized global healthcare policies and management. Clinicians also need to be trained with updated interim guidance on the effective, safe, efficient and prompt supportive management of the nCOVID-19 patients especially those who are admitted to the hospital with severe respiratory illness. The hospital authority should ensure that the clinical management of the patient and patient care should be started from the entry point of the hospital to reduce the risk of the contamination. It is important to implement the application of telemedicine and video consultations for regular health checkups and nonemergency cases to avoid the unnecessary contamination of the patients as well as health care professionals [199]. On the other hand, governments are responsible for social management like the implementation of strategies, rules, guidelines for food habits to prevent the recurrence of this type of disease in the future. The rules regarding the prohibition on consumption of fast foods, raw uncooked food eating should be taken into strict considerations, as food consumption is the probable reason behind the initiation of nCOVID-19 infections. While the sudden socio-economic turmoil is been taken care of by the government, personal safety, wellbeing, health, and hygiene is the responsibility of each one of the citizens. However, long term protection against nCOVID-19 is only possible when immune boosting can be achieved scientifically as well as by taking up certain changes in habits in daily lives such as consumption of fruits, antioxidants, exercise, yoga, proper sleep, and a routine healthy lifestyle. Finally, it may be stated that this is wise to pay proper scientific attention to the current situation and take it as a lesson for the future in all possible aspects of life.

\section{References}

1. Su S, Wong G, Shi W, Liu J, Lai A, et al. (2016) Epidemiology, Genetic Recombination, and Pathogenesis of Coronaviruses Trends in microbiology 24: 490-502. Link: https://bit.ly/3e4jiOE

2. Zhu N, Zhang D, Wang W, Li X, Yang BA, et al. (2020) Novel coronavirus from patients with pneumonia in China, 2019. N Engl J Med 382: 727-733. Link: https://bit.ly/2CaCDQY

3. Link: https://www.who.int/docs/default-source/coronaviruse/20200630-cov id-19-sitrep-162.pdf?sfvrsn=e00a5466_2

4. Link:https://www.who.int/docs/default-source/coronaviruse/situationreports/20200418-sitrep-89-covid-19.pdf

5. Wu C, Chen X, Cai Y (2020) Risk Factors Associated With Acute Respiratory Distress Syndrome and Death in Patients With Coronavirus Disease, 2019 Pneumonia in Wuhan, China JAMA Intern Med Link: https://bit.ly/2VQnkEb

6. D“Adamo H, Yoshikawa T, Ouslander JG (2020) Coronavirus Disease 2019 in Geriatrics and Long-term Care: The ABCDs of COVID-19. J Am Geriatr Soc Link: https://bit.ly/3f6nAGS

7. Zhang L, Ma L, Sun F, Tang Z, Chan P (2020) A Multicenter Study of Multimorbidity in Older Adult In patients in China. J Nutr Health Aging 24: 269 276. Link: https://bit.ly/2NWIfkq
8. Roy D, Tripathy S, Kar SK, Sharma N, Verma SK, et al. (2020) Study of knowledge, attitude, anxiety \& perceived mental healthcare need in Indian population during COVID-19 pandemic. Asian J Psychiatr 51: 102083. Link: https://bit.ly/38ub7tw

9. Cullen W, Gulati G, Kelly BD (2020) Mental health in the Covid-19 pandemic QJM pii: hcaa110. Link: https://bit.ly/2ZDbkah

10. Chakraborty I, Maity P (2020) COVID-19 outbreak: Migration, effects on society, global environment and prevention. Sci Total Environ 728: 138882. Link: https://bit.ly/2W5SOXd

11. Mahony JB, Petrich A, Smieja M (2011) Molecular diagnosis of respiratory virus infections. Crit Rev Clin Lab Sci 48: 217-249. Link: https://bit.ly/3f6nO0G

12. Azar MM, Landry ML (2018) Detection of influenza A and B viruses and respiratory syncytial virus by use of Clinical Laboratory Improvement Amendments of 1988 (CLIA)waived point-of-care assays: a paradigm shift to molecular tests. J Clin Microbiol 56: e00367-18. Link: https://bit.ly/3golgKe

13. Zhang N, Wang L, Deng X, et al. (2020) Recent advances in the detection of respiratory virus infection in humans. J Med ssVirol 92: 408- 417. Link: Link: https://bit.ly/2CbQN4h

14. Kubo T, Agoh M, Mai LQ, Fukushima K, Yamaguchi A, et al. (2010) Development of a reverse transcription-loop-mediated isothermal amplification assay for detection of pandemic (H1N1) 2009 virus as a novel molecular method for diagnosis of pandemic influenza in resource-limited settings. J Clin Microbiol 48: 728-735. Link: https://bit.ly/31NJB9B

15. Zhang P, Vemula SV, Zhao J, Du B, Mohan H, et al. (2014) A highly sensitive europium nanoparticle-based immunoassay for detection of influenza $A / B$ virus antigen in clinical specimens. J Clin Microbiol 52: 4385-4387. Link: https://bit.ly/3gsh1P0

16. Vemula SV, Zhao J, Liu J, Wang X, Biswas S, et al. (2016) Current approaches for diagnosis of influenza virus infections in humans. Viruses 8: 96 . Link: https://bit.ly/2DdXxPS

17. Trombetta VK, Chan YL, Bankowski MJ (2018) Are rapid influenza antigen tests still clinically useful in today's molecular diagnostics world? Hawaii J Med Public Health 77: 226-230. Link: https://bit.ly/200CnqG

18. Simpson R, Aliyu S, Iturriza-Gomara M, Desselberger U, Gray J (2003) Infantile viral gastroenteritis: On the way to closing the diagnostic gap. J Med Virol 70: 258-262. Link: https://bit.ly/2Z1fqtr

19. Shimada Y, Ariga T, Tagawa Y, Aoki K, Ohno S, et al. (2004) Molecular diagnosis of human adenoviruses $D$ and $E$ by a phylogeny-based classification method using a partial hexon sequence. J Clin Microbiol 42:1577-1584. Link: https://bit.ly/2NWIBHM

20. Madisch I, Wolfel R, Harste G, Pommer H, Heim A (2006) Molecular identification of adenovirus sequences: a rapid scheme for early typing of human adenoviruses in diagnostic samples of immunocompetent and immunodeficient patients. J Med Virol 78: 1210-1217. Link: https://bit.ly/3iFFpPh

21. Zhang Q, Jing S, Cheng Z, Yu Z, Dehghan S et al. (2017) Comparative genomic analysis of two emergent human adenovirus type 14 respiratory pathogen isolates in China reveals similar yet divergent genomes. Emerg Microbes Infect 6: e92. Link: https://bit.ly/2C5ueyu

22. Kim MN, K YJ, Seong MW, Kim JS, Shi BM, et al. (2016) Analytical and clinical validation of six commercial Middle East respiratory syndrome coronavirus RNA detection kits based on real-time reverse-transcription PCR. Ann Lab Med 36: 450-456. Link: https://bit.ly/2YZQ4fJ

23. Hashemzadeh MS, Rasouli R, Zahraei B, Izadi M, Tat M, et al. (2016) Development of Dual TaqMan based one-step rRT-PCR assay panel for rapid and accurate diagnostic test of MERS-CoV: a novel human coronavirus, ahead of Hajj Pilgrimage. Iran Red Crescent Med J 18: e23874. Link: https://bit.ly/310nLm4

Citation: Poddar MK, Chakraborty A (2020) nCOVID-19: Its diagnosis, possible preventive measures, therapeutic interventions and management. Arch Community Med Public Health 6(2): 115-129. DOI: https://dx.doi.org/10.17352/2455-5479.000090 
24. Go YY, Kim YS, Cheon S, Nam S, Ku KB et al. (2017) Evaluation and clinical validation of two field-deployable reverse transcription-insulated isothermal PCR assays for the detection of the Middle East respiratory syndromecoronavirus. J Mol Diagn 19: 817-827. Link: https://bit.ly/38vGwMw

25. Shirato K, Semba S, El-Kafrawy SA, Hassan AM, Tolah AM, et al. (2018) Development of fluorescent reverse transcription loop-mediated isothermal amplification (RTLAMP) using quenching probes for the detection of the Middle East respiratory syndrome coronavirus. J Virol Methods 258: 41-48. Link: https://bit.ly/2ZD3u0c

26. Myatt TA, Johnston SL, Rudnick S, Milton DK (2003) Airborne rhinovirus detection and effect of ultraviolet irradiation on detection by a seminested RT-PCR assay. BMC Public Health 3: 5. Link: https://bit.ly/2YZR2bS

27. Do DH, Laus S, Leber A, Marcon MJ, Jordan JA, et al. (2010) A one-step, realtime PCR assay for rapid detection of rhinovirus. J Mol Diagn 12: 102-108. Link: https://bit.ly/2Cau7kW

28. Schibler M, Yerly S, Vieille G, Docquier M, Turin L, et al. (2012) Critical analysis of rhinovirus RNA load quantification by real-time reverse transcription-PCR. J Clin Microbiol 50: 2868-2872. Link: https://bit.ly/31TWzCN

29. Slinger R, Milk R, Gaboury I, Diaz-Mitoma F (2004) Evaluation of the QuickLab RSV test, a new rapid lateral-flow immunoassay for detection of respiratory syncytial virus antigen. J Clin Microbiol 42: 3731-3733. Link: https://bit.ly/3f5916d

30. Borek AP, Clemens SH, Gaskins VK, Aird DZ, Valsamakis A (2006) Respiratory syncytial virus detection by remel Xpect, Binax Now RSV direct immunofluorescent staining, and tissue culture. J Clin Microbiol 44 1105-1107. Link: https://bit.ly/2NZolW5

31. Selvarangan R, Abel D, Hamilton M (2008) Comparison of BD Directigen (TM) EZ RSV and Binax NOW (R) RSV tests for rapid detection of respiratory syncytial virus from nasopharyngeal aspirates in a pediatric population. Diagn Microbiol Infec Dis 62: 157-161. Link: https://bit.ly/2VPe1oa

32. Lim XF, Lee CB, Pascoe SM, How CB, Chan S et al. (2019) Detection and characterization of a novel bat-borne coronavirus in Singapore using multiple molecular approaches. J Gen Virol 100: 1363-1374. Link: https://bit.ly/3f3wkND

33. Wang N, Luo C, Liu H, Yang X, Hu B, et al. (2019) Characterization of a new member of alphacoronavirus with unique genomic features in rhinolophus bats. Viruses 11: E379. Link: https://bit.ly/2AyyoOX

34. Huang $P$, Wang $H$, Cao $Z$, Jin $H$, Chi $H$, et al. (2018) A rapid and specific assay for the detection of MERS-CoV. Front Microbiol 9: 1101. Link: https://bit.ly/2z08ooQ

35. Cleri DJ, Ricketti AJ, Vernaleo JR (2010) Severe acute respiratory syndrome (SARS) Infect. Dis Clin North Am 24: 175-202. Link: https://bit.ly/3gvOS9L

36. Guan Y, Zheng B, He Y, Liu X, Zhuang Z, et al. (2003) Isolation and characterization of viruses related to the SARS coronavirus from animals in Southern China. Science 302: 276-278. Link: https://bit.ly/31NQsji

37. Woo PCY, Lau SKP, Huang Y, Yuen KY (2009) Coronavirus diversity, phylogeny and interspecies jumping. Exp Biol Med 234: 1117-1127. Link: https://bit.ly/3grl0dB

38. Denison MR, Graham RL, Donaldson EF, Eckerle LD, Baric RS (2011) Coronaviruses: an RNA proofreading machine regulates replication fidelity and diversity RNA Biol 8: 270-279. Link: https://bit.ly/2ABRLGS

39. Holmes E (2009) The evolution and emergence of RNA viruses. In Oxford Series in Ecology and Evolution. Edited by Harvey PH, May RM. Oxford University Press Link: https://bit.ly/38sFT6w

40. Corman VM, Eckerle I, Bleicker T, Zaki A, Landt O, et al (2012) Detection of a novel human coronavirus by real-time reverse-transcription polymerase chain reaction. Euro Surveill 17: 20185. Link: https://bit.ly/38teQI6
41. Zaki AM, van Boheemen S, Bestebroer TM, Osterhaus AD, Fouchier RA (2012) Isolation of a novel Coronavirus from a man with pneumonia in Saudi Arabia. N Engl J Med 367: 1814-1820. Link: https://bit.ly/31MzzFv

42. Hu B, Ge X, Wang LF, Shi Z (2015) Bat origin of human coronaviruses. Virol J 12: 221. Link: https://bit.ly/3ilQqPM

43. Middle East respiratory syndrome coronavirus (MERS-CoV). WHO. Link: https://bit.ly/2De2BDT

44. Xu J, Zhao S, Teng T, Abdalla AE, Zhu W, et al. (2020) Systematic comparision of two Animal-to Human Transmitted Human Coronaviruses: SARS-CoV-2 and SARS-CoV. Viruses 22: 12. pii: E244. Link: https://bit.ly/3e2yrjF

45. Wang C, Horby PW, Hayden FG, Gao GF (2020) A novel coronavirus outbreak of global health concern. Lancet 395: 470-473. Link: https://bit.ly/2DdZbB2

46. Yang Y, Lu Q, Liu M, Wang Y, Zhang A, et al. (2020). Epidemiological and clinical features of the 2019 novel coronavirus outbreak in China. medRxiv Link: https://bit.ly/2VOEv9b

47. Simmons G, Zmora P, Gierer S, Heurich A, Pöhlmann S (2013) Proteolytic activation of the SARS-coronavirus spike protein: cutting enzymes at the cutting edge of antiviral research. Antiviral Res 100: 605-614. Link: https://bit.ly/2ZIBFDB

48. Li F, Li W, Farzan M, Harrison SC (2005) Structural biology: Structure of SARS coronavirus spike receptor-binding domain complexed with receptor. Science 309: 1864-1868. Link: https://bit.ly/2YZwnES

49. Millet JK, Whittaker GR (2015) Host cell proteases: Critical determinants of coronavirus tropism and pathogenesis. Virus Res 202: 120-134. Link: https://bit.ly/3f1eMC4

50. Wrapp D, Wang N, Corbett KS, Goldsmith JA, Hsieh CL, et al. (2020) CryoEM structure of the 2019-nCoV spike in the prefusion conformation Science eabb2507. Link: https://bit.ly/3grlDDZ

51. Donoghue $M$, Hsieh F, Baronas E, Godbout K, Gosselin M, et al. (2002) A Novel Angiotensin-Converting Enzyme-Related Carboxypeptidase (ACE2) Converts Angiotensin I to Angiotensin 1-9 Circ Res 87: E1-E9. Link: https://bit.ly/2VM7HNR

52. Zhang $H$, Kang Z, Gong $H, X u ~ D$, Wang J, et al. (2020) The digestive system is a potential route of 2019-nCov infection: a bioinformatics analysis based on single-cell transcriptomes bioRxiv 2020.01.30.927806 Link: https://bit.ly/2NXETxV

53. Yan R, Zhang Y, Li Y, Xia L, Guo Y, et al. (2020) Structural basis for the recognition of SARS-CoV-2 by full-length human ACE2 Science 367:14441448. Link: https://bit.ly/2NYnEMP

54. Guo YR, Cao QD, Hong ZS, Tan YY, Chen SD, et al. (2020) The origin transmission and clinical therapies on coronavirus disease 2019 (COVID- 19) outbreak - an update on the status. Mil Med Res 7: 11. Link: https://bit.ly/3grIG2D

55. Ou X, Liu Y, Lei X, Li P, Mi D, et al. (2020) Characterization of spike glycoprotein of SARS-CoV-2 on virus entry and its immune cross-reactivity with SARS-CoV. Nat Commun 11: 1620. Link: https://go.nature.com/2Z1gLjX

56. Gemmati D, Bramanti B, Serino ML, Secchiero P, Zauli, G, et al. (2020) COVID-19 and Individual Genetic Susceptibility/Receptivity: Role of ACE1/ ACE2 Genes, Immunity, Inflammation and Coagulation. Might the Double $\mathrm{X}$-Chromosome in Females Be Protective against SARS-CoV-2 Compared to the Single X-Chromosome in Males? Int J Mol Sci 21: 3474. Link: https://bit.ly/2BzM2ls

57. Kawase M, Shirato K, van der Hoek L, Taguchi F, Matsuyama S (2012) Simultaneous treatment of human bronchial epithelial cells with serine and cysteine protease inhibitors prevents severe acute respiratory syndrome coronavirus entry. J Virol 86: 6537-6545. Link: https://bit.ly/2Z3BNyB

Citation: Poddar MK, Chakraborty A (2020) nCOVID-19: Its diagnosis, possible preventive measures, therapeutic interventions and management. Arch Community Med Public Health 6(2): 115-129. DOI: https://dx.doi.org/10.17352/2455-5479.000090 
58. Zhou Y, Vedantham P, Lu K, Agudelo J, Carrion R, et al. (2015) Protease inhibitors targeting coronavirus and filovirus entry. Antiviral Res 116: 76-84. Link: https://bit.ly/3gy9eiP

59. Iwata-Yoshikawa N, Okamura T, Shimizu Y, Hasegawa H, Takeda M, et al (2019) TMPRSS2 Contributes to Virus Spread and Immunopathology in the Airways of Murine Models after Coronavirus Infection. J Virol 93 Link: https://bit.ly/2NVxVcH

60. Hoffmann $M$, Kleine-Weber $H$, Schroeder S, Kruger $N$, Herrleer $T$, et al. (2020) SARSCoV-2 Cell Entry Depends on ACE2 and TMPRSS2 and Is Blocked by a Clinically Proven Protease Inhibitor. Cell 181: 271-280. Link: https://bit.ly/2BxcqMQ

61. Gierer S, Bertram S, Kaup F, Wrensch F, Heurich A, et al. (2013) The spike protein of the emerging betacoronavirus EMC uses a novel coronavirus receptor for entry, can be activated by TMPRSS2, and is targeted by neutralizing antibodies. J Virol 87: 5502-5511. Link: https://bit.ly/31Pq48K

62. Glowacka I, Bertram S, Muller MA, Allen P, Soilleux E, et al. (2011) Evidence that TMPRSS2 activates the severe acute respiratory syndrome coronavirus spike protein for membrane fusion and reduces viral control by the humoral immune response. J Virol 85 : 4122-4134. Link: https://bit.ly/38tWp6h

63. Lan J, Ge J, Yu J, Shan S, Zhou H, et al. (2020) Structure of the SARS-CoV-2 spike receptor-binding domain bound to the ACE2 receptor. Nature Link: https://bit.ly/3gyajXV

64. Shi Y, Wang Y, Shao C, Huang J, Gan J, et al. (2020) COVID-19 infection: the perspectives on immune responses. Cell Death Differ 27: 1451-1454. Link: https://bit.ly/2VMRGHu

65. Ellinghaus D, Degenhardt F, Bujanda L, Buti M, Albillos A (2020) Genomewide Association Study of Severe Covid-19 with Respiratory Failure. New England Journal of Medicine Link: https://bit.ly/2ABSPKS

66. Xu Z, Shi L, Wang Y, Zhang J, Huang L, et al. (2020) Pathological findings of COVID-19 associated with acute respiratory distress syndrome. The Lancet Respiratory medicine. Link: https://bit.ly/2VOZbOK

67. Lagunas-Rangel FA, Chávez-Valencia V (2020) High IL-6/IFN-ץ ratio could be associated with severe disease in COVID-19 patients. J Med Virol Link: https://bit.ly/2BGoBqv

68. Canna SW, Behrens EM (2012) Making sense of the cytokine storm: a conceptual framework for understanding, diagnosing, and treating hemophagocytic syndromes. Pediatric clinics of North America 59: 329-344. Link: https://bit.ly/2DavD7f

69. Huang C, Wang Y, Li X, Ren L, Zhao J, et al. (2020) Clinical features of patients infected with 2019 novel coronavirus in Wuhan, China. Lancet 395: 497-506. Link: https://bit.ly/2YKFlpn

70. Qin C, Zhou L, Hu Z, Zhang S, Yang S, et al. (2020) Dysregulation of immune response in patients with COVID-19 in Wuhan, China. Clin Infect Dis Link: https://bit.ly/2BK6dNk

71. Shi Y, Tan M, Chen X, Yanxia L, Huang J, et al. (2020) Immunopathological characteristics of coronavirus disease 2019 cases in Guangzhou, China. medRxiv Link: https://bit.ly/31MYjgV

72. Zhang B, Zhou X, Zhu C, Feng F, Yanru Q, et al. (2020) Immune phenotyping based on neutrophil- tolymphocyte ratio and IgG predicts disease severity and outcome for patients with COVID-19. Preprint at medRxiv Link: https://bit.ly/2ZJM81X

73. Chen X, Ling J, Mo P, Zhang Y, Qunqun J, et al. (2020) Restoration of leukomonocyte counts is associated with viral clearance in COVID-19 hospitalized patients. Preprint at medRxiv Link: https://bit.ly/200BIpa

74. Zheng M, Gao Y, Wang G, Goubin S, Liu S, et al. (2020) Functional exhaustion of antiviral lymphocytes in COVID-19 patients. Cell Mol Immunol Link: https://bit.ly/3eYmj4q
75. Shen C, Wang Z, Zhao F (2020) Treatment of 5 critically ill patients with COVID-19 with convalescent plasma. JAMA Link: https://bit.ly/3ffV45L .

76. Guan WJ, Ni ZY, Hu Y, Liang WH, Ou CQ, et al. (2020) China Medical Treatment Expert Group for Covid-19. Clinical Characteristics of Coronavirus Disease 2019 in China. N Engl J Med Link: https://bit.ly/2Z4LEnX

77. Wang YD, Zhang SP, Wei QZ, Zhao MM, Mei H, et al. (2020) COVID-19 complicated with DIC: 2 cases report and literatures review Zhonghua Xue Ye Xue Za Zhi Zhonghua Xueyexue Zazhi 41: E001. Link: https://bit.ly/2ZEXh3Y

78. Tang N, Li D, Wang X, Sun Z (2020) Abnormal coagulation parameters are associated with poor prognosis in patients with novel coronavirus pneumonia. J Thromb Haemost JTH 18: 844-847. Link: https://bit.ly/3e4uX07

79. Lippi G, Plebani M, Michael Henry B (2020) Thrombocytopenia is associated with severe coronavirus disease 2019 (COVID-19) infections: A meta-analysis. Clin Chim Acta 506: 145-148. Link: https://bit.ly/3e6DXIg

80. Subramaniam S, Scharrer I (2018) Procoagulant activity during viral infections Front Biosci 23: 1060-1081. Link: https://bit.ly/38sJL7B

81. van Gorp ECM, Suharti C, ten Cate H, Dolmans WMV, van der Meer JWM, et al (1999) Review: Infectious Diseases and Coagulation Disorders. J Infect Dis 180: 176-186. 10.1086/314829 Link: https://bit.ly/3gzuvIV

82. Guo L, Rondina MT (2019) The Era of Thromboinflammation: Platelets Are Dynamic Sensors and Effector Cells During Infectious Diseases Front. Immunol 10: 2204. Link: https://bit.ly/2Z1i6Y2

83. Franz-Josef N, Nikolaus M, Meinrad G, Korbinian B, Ilka V, et al. (1997) Induction of Cytokine Expression in Leukocytes by Binding of ThrombinStimulated Platelets Circulation, 95 : 2387-2394. Link: https://bit.ly/2Dax1GZ

84. Xiang $P$, Xu XM, Gao LL, Wang HZ, Xiong HF, et al. (2020) First case of 2019 novel coronavirus disease with Encephalitis. ChinaXiv T202003:00015.

85. Anderson EL, Turnham P, Griffin JR, Clarke CC (2020) Consideration of the Aerosol Transmission for COVID-19 and Public Health. Risk Anal 40: 902-907. Link: doi:10.1111/risa. 13500

86. Bassetti M, Vena A, Giacobbe DR (2020) The novel Chinese coronavirus (2019-nCoV) infections: challenges for fighting the storm. Eur J Clin Invest 50 e13209. Link: https://bit.ly/2ZILCAW

87. Link: https://www.who.int/dg/speeches/detail/who-director-general-s-opening-remarks-at-themedia-briefing-on-covid-19---11-march-2020

88. Xiao F, Tang M, Zheng X, Liu Y, Li X, et al. (2020) Evidence for Gastrointestinal Infection of SARS-CoV-2. 158: 1831-1833. Link: https://bit.ly/2O0EsTu

89. Carbone F, Bodini G, Brunacci M, Bonaventura A, Vecchiè A, et al. (2018) Reduction in TIMP-2 serum levels predicts remission of inflammatory bowe diseases. Eur J Clin Invest 48: e13002. Link: https://bit.ly/2VN1IIY

90. Zhang H, Kang Z, Gong H, Xu D (2020) Digestive system is a potential route of COVID-19: an analysis of single-cell coexpression pattern of key proteins in viral entry process Gut. Link: https://bit.ly/2BxpnGr

91. Ye M, Ren Y, Lv T (2020) Encephalitis as a clinical manifestation of COVID-19. Brain Behav Immun S0889-1591: 30465-30467. Link: https://bit.ly/2C83wVW

92. Hong KH, Lee SW, Kim TS, Huh HJ, Lee J, et al. (2020) Guidelines for Laboratory Diagnosis of Coronavirus Disease 2019 (COVID-19) in Korea. Ann Lab Med 40: 351360. Link: https://bit.ly/2ZHcAcs

93. Link: https://www.who.int/publications-detail/laboratory-testing-for-2019novel-coronavirus-in-suspected-human-cases-20200117

94. Corman VM, Landt O, Kaiser M, Molenkamp R, Meijer A, et al. (2020) Detection of 2019 novel coronavirus (2019-nCoV) by real-time RT-PCR. Euro Surveill 25 2000045. Link: https://bit.ly/3ivfZnc

Citation: Poddar MK, Chakraborty A (2020) nCOVID-19: Its diagnosis, possible preventive measures, therapeutic interventions and management. Arch Community Med Public Health 6(2): 115-129. DOI: https://dx.doi.org/10.17352/2455-5479.000090 
95. Chu DKW, Pan Y, Cheng SMS, Hui KPY, Krishnan P, et al. (2020) Molecular diagnosis of a novel coronavirus (2019-nCoV) causing an outbreak of pneumonia. Clin Chem pii: hvaa029. Link: https://bit.ly/3iBY8Lh

96. Link: https://www.who.int/docs/default-source/coronaviruse/conventionalrt-pcr-followed-by-sequencing-for-detection-of-ncov-rirl-nat-inst-health-t.pdf.

97. Link: https://www.who.int/docs/default-source/coronaviruse/real-time-rtpcr-assays-for-the-detection-of-sars-cov-2-institut-pasteur-paris.pdf

98. Link: https://www.cdc.gov/coronavirus/2019-ncov/downloads/rt-pcr-panelfor-detection-instructions.pdf

99. Link: https://www.who.int/emergencies/diseases/novel-coronavirus-2019/ technical-guidance/laboratory-guidance

100. Chen Y, Chen L, Deng Q, Zhang G, Wu K, et al. (2020) The presence of SARS CoV- 2 RNA in feces of COVID- 19 patients. J Med Virol 92: 833-840. Link: https://bit.ly/2VQuZSX

101. Zhang J, Wang S, Xue Y (2020) Fecal specimen diagnosis 2019 nove coronavirus-infected pneumonia. J Med Virol 92: 680-682. Link: https://bit.ly/2BJrxCF

102. Nouri-Vaskeh M, Alizadeh L (2020) Fecal transmission in COVID-19: A potential shedding route. J Med Virol Link: https://bit.ly/2ZEIIOn

103. Jiang X, Luo M, Zou Z, Wang X, Chen C, et al. (2020) Asymptomatic SARS-CoV-2 infected case with viral detection positive in stool but negative in nasopharyngeal samples lasts for 42 days. J Med Virol Link: https://bit.ly/3eYic8x

104. Link: https://www.who.int/news-room/commentaries/detail/advice-onthe-use-of-point-of-care-immunodiagnostic-tests-for-covid-19

105. Bruning AHL, Leeflang MMG, Vos JMBW, Spijker R, de Jong MD, et al. (2020) Rapid Tests for Influenza, Respiratory Syncytial Virus, and Other Respiratory Viruses: A Systematic Review and Meta-analysis. Clin Infect Dis 65: 10261032. Link: https://bit.ly/2W69YE7

106. Liu Y, Liu Y, Diao B, Feifei R, Wang Y, et al. (2020) Diagnostic indexes of a rapid IgG/IgM combined antibody test for SARS-CoV-2. Medxriv Link: https://bit.ly/38tXRp2

107. Zhang $P$, Gao Q, Wang T, Ke Y, Mo F, et al. (2020) Evaluation of recombinant nucleocapsid and spice protein serological diagnosis of novel coronavirus disease 2019 (COVID-19). Medxriv. Link: https://bit.ly/3it2vbH

108. Zhao J, Yuan Q, Wang H, Liu W, Liao X, et al. (2020) Antibody responses to SARS-CoV-2 in patients of novel coronavirus disease 2019. medxriv Link https://bit.ly/31IYQ3w

109. Okba NMA, Muller MA, Li W, Wang C, Corine H, et al. (2020) SARS COV-2 specific antibody responses in COVID-19 patients. medxriv Link: https://bit.ly/31IYQ3w

110. Wölfel R, Corman V, Guggemos W, Seilmaier M, Mueller M, et al. (2020) Virological assessment of hospitalized patients with COVID-2019. Nature Link: https://go.nature.com/31MPzrd

111. Wang N, Li SY, Yang XL, Huang HM, Zhang YJ, et al. (2018) Serologica Evidence of Bat SARS-Related Coronavirus Infection in Humans, China. Virol Sin 33: 104-107. doi:10.1007/s12250-018-0012-7 Link: https://bit.ly/3iAGyaw

112. Che XY, Qiu LW, Liao ZY, Wang YD, Wen K, et al. (2005) Antigenic crossreactivity between severe acute respiratory syndrome-associated coronavirus and human coronaviruses $229 \mathrm{E}$ and OC43. The Journal of Infectious Diseases 191: 2033-2037 Link: https://bit.ly/2Z3JmF

113. Link: http://en.nhc.gov.cn/2020-03/29/c_78469.htm
114. Jin YH, Cai L, Cheng ZS, Cheng H, Deng T, et al. (2020) A rapid advice guideline for the diagnosis and treatment of 2019 novel coronavirus (2019$\mathrm{nCoV}$ ) infected pneumonia (standard version). Military Med Res 7: 4 Link: https://bit.ly/2Z2jVUX

115. Home care for patients with suspected novel coronavirus (2019-nCoV) infection presenting with mild symptoms and management of contacts: interim guidance. Link: https://bit.ly/2VLAUZq

116. Link: https://www.who.int/publications/i/item/infection-prevention-andcontrol-during-health-care-when-novel-coronavirus-(ncov)-infection-issuspected-20200125

117. Link: https://www.who.int/news-room/articles-detail/who-advice-forinternational-travel-and-trade-in-relation-to-the-outbreak-of-pneumoniacaused-by-a-new-coronavirus-in-china

118. Link: https://www.ayush.gov.in/docs/naturopathy-guidelines.pdf

119. Link: https://www.un.org/en/coronavirus/wellness

120. Falkenberg RI, Eising C, Peters ML (2018) Yoga and immune system functioning: a systematic review of randomized controlled trials. J Behav Med 41: 467-482. Link: https://bit.ly/31UTsds

121. Link: https://homeopathic.com/some-vital-facts-about-covid-19-and-what natural-medicine-offers/

122. Bracho G, Varela E, Fernández R, Ordaz B, Marzoa N, et al. (2010) Large scale application of highly-diluted bacteria for Leptospirosis epidemic control. Homeopathy 99: 156-166. Link: https://bit.ly/3gw6YbH

123. Link: https://homeopathic.com/some-vital-facts-about-covid-19-and-whatnatural-medicine-offers/

124. Link: https://www.newindianexpress.com/nation/2020/apr/30/40-percent-of-covid-19-clinical-trials-involve-ayush-but-most-could-be-of-lowquality-2137538.htm

125. Thurnham DI (1997) Micronutrients and immune function: some recent developments. J Clin Pathol 50: 887-891. Link: https://bit.ly/31PwlkG

126. Chandra RK (1992) Effect of vitamin and trace-element supplementation on immune responses and infection in elderly subjects. Lancet 340:1124 1127. Link: https://bit.ly/38u805j

127. Muscogiuri G, Barrea L, Savastano S, Colao A (2020) Nutritional recommendations for COVID-19 quarantine. Eur J Clin Nutr Link: https://bit.ly/2ZOkZs8

128. Te Velthuis AJ, van den Worm SH, Sims AC, Baric RS, Snijder EJ, et al. (2010) $\mathrm{Zn}(2+)$ inhibits coronavirus and arterivirus RNA polymerase activity in vitro and zinc ionophores block the replication of these viruses in cell culture. PLoS Pathog 6: e1001176. Link: https://bit.ly/31RKspB

129. Sanders JM, Monogue ML, Jodlowski TZ, Cutrell JB (2020) Pharmacologic Treatments for Coronavirus Disease 2019 (COVID-19): A Review. JAMA. Link: https://bit.ly/2Z366W6

130. Zhou D, Dai SM, Tong Q (2020) COVID-19:a recommendation to examine the effect of hydroxychloroquine in preventing infection and progression. $J$ Antimicrob Chemother 75: 1667-1670. Link: https://bit.ly/2Z1spLI

131. Devaux CA, Rolain JM, Colson P, Raoult D (2020) New insights on the antiviral effects of chloroquine against coronavirus: what to expect for COVID-19? Int J Antimicrob Agents 55: 105938. Link: https://bit.ly/3idoCTb

132. Yao X, Ye F, Zhang M, Cui C, Huang B, et al. (2020) In Vitro Antiviral Activity and Projection of Optimized Dosing Design of Hydroxychloroquine for the Treatment of Severe Acute Respiratory Syndrome Coronavirus 2 (SARSCoV-2). Clin Infect Dis. Link: https://bit.ly/3gp2gwi

133. Inglot AD (1969) Comparison of the antiviral activity in vitro of some

Citation: Poddar MK, Chakraborty A (2020) nCOVID-19: Its diagnosis, possible preventive measures, therapeutic interventions and management. Arch Community Med Public Health 6(2): 115-129. DOI: https://dx.doi.org/10.17352/2455-5479.000090 
non-steroidal antiinflammatory drugs. J Gen Virol 4: 203-214. Link: https://bit.ly/2VN9ySA

134. Miller DK, Lenard J (1981) Antihistaminics, local anesthetics, and othe amines as antiviral agents. Proc Natl Acad Sci U S A 78: 3605-3609. Link: https://bit.ly/3gq3fw8

135. Silva JA, Silva MB, Skare TL (2007) Chloroquine and QTc interval. Clin Exp Rheumatol 25: 795. Link: https://bit.ly/3gs0TNx

136. Gautret P, Lagier JC, Parola P, Hoang VT, Meddeb L, et al. (2020) Hydroxychloroquine and azithromycin as a treatment of COVID-19: results of an open-label non-randomized clinical trial. Int J Antimicrob Agents Link: https://bit.ly/3fg6qGV

137. Borba MGS, Val FFA, Sampaio VS, Alexandre MAA, Melo GC, et al. (2020) Effect of High vs Low Doses of Chloroquine Diphosphate as Adjunctive Therapy for Patients Hospitalized With Severe Acute Respiratory Syndrome Coronavirus 2 (SARS-CoV-2) Infection: A Randomized Clinical Trial. JAMA Netw Open 3: e208857. Link: https://bit.ly/3gwBMcs

138. Chu C, Cheng V, Hung I, Wong M, Chan K, et al. (2004) Role of lopinavir/ ritonavir in the treatment of SARS: initial virological and clinical findings. Thorax 59: 252-256. Link: https://bit.ly/38xeVuv

139. de Wilde AH, Jochmans D, Posthuma CC, Zevenhoven-Dobbe JC Nieuwkoop SV, et al. (2014) Screening of an FDA-approved compound library identifies four small-molecule inhibitors of Middle East respiratory syndrome coronavirus replication in cell culture. Antimicrob Agents Chemother 58: 4875-4884. Link: https://bit.ly/2BKnaHs

140. Dong L, Hu S, Gao J (2020) Discovering drugs to treat coronavirus disease 2019 (COVID19) Drug Discov Ther 14: 58-60. Link: https://bit.ly/3iDd8J8

141. Yao TT, Qian JD, Zhu WY, Wang Y, Wang GQ (2020) A systematic review of lopinavir therapy for SARS coronavirus and MERS coronavirus-A possible reference for coronavirus disease-19 treatment option J Med Virol 92: 556563. Link: https://bit.ly/2Z4NEwu

142. Chan KS, Lai ST, Chu CM, et al. (2003) Treatment of severe acute respiratory syndrome with lopinavir/ritonavir: a multicentre retrospective matched cohort study. Hong Kong Med J 9: 399-406. Link: https://bit.ly/2017gem

143. Link: https://www.chinalawtranslate.com/wp-content/ uploads/2020/03/ Who-translation.pdf

144. Cao B, Wang Y, Wen D, Liu W, Wang J, et al. (2020) A trial of lopinavirritonavir in adults hospitalized with severe COVID-19. N Engl J Med 382 Link: https://bit.ly/2VOWSe9

145. Report available at: Lopinavir/ritonavir [database online]. Hudson $(\mathrm{OH})$ Lexicomp Inc; 2016. http://online.lexi.com

146. Stockman LJ, Bellamy R, Garner P (2006) SARS: systematic review of treatment effects. PloS Med 3: e343. Link: https://bit.ly/2DePeTV

147. Altınbas S, Holmes JA, Altınbas A (2020) Hepatitis C virus infection in pregnancy: an update. Gastroenterol Nurs 43: 12-21. Link: https://bit.ly/2ZEVADJ

148. Wang D, Hu B, Hu C, Zhu F, Liu X, et al. (2020) Clinical characteristics of 138 hospitalized patients with 2019 novel coronavirus-infected pneumonia in Wuhan, China. JAMA Link: https://bit.ly/2C47VZT

149. ClinicalTrials.gov is a database of privately and publicly funded clinical studies conducted around the world. Link: https://bit.ly/3gwanat

150. Kadam RU, Wilson IA (2017) Structural basis of influenza virus fusion inhibition by the antiviral drug Arbidol. Proc Natl Acad Sci U S A 114: 206214. Link: https://bit.ly/3gs2C5t

151. Khamitov RA, Loginova SI, Shchukina VN, Borisevich SV, Maksimov VA et al. (2008) Antiviral activity of arbidol and its derivatives against the pathogen of severe acute respiratory syndrome in the cell cultures. Vopr Virusol 53: 9-13. Link: https://bit.ly/2BGIsWA

152. Wang Z, Yang B, Li Q, Wen L, Zhang R (2020) Clinical Features of 69 cases with coronavirus disease 2019 in Wuhan, China. Clin Infect Dis Link: https://bit.ly/2VNnxb2

153. Siegel D, Hui HC, Doerffler E, Clarke MO, Chun K, et al. (2017) Discovery and synthesis of a phosphoramidate prodrug of a pyrrolo [2,1-f] [triazin-4-amino] adenine C-nucleoside (GS-5734) for the treatment of Ebola and emerging viruses. J Med Chem 60: 1648-1661. Link: https://bit.ly/3f4LulQ

154. Furuta Y, Komeno T, Nakamura T (2017) Favipiravir (T-705), a broad spectrum inhibitor of viral RNA polymerase. Proc Jpn Acad Ser B Phys Biol Sci 93: 449-463. Link: https://bit.ly/2Z2YPFW

155. Wang M, Cao R, Zhang L, Yang X, Liu J, et al. (2020) Remdesivir and chloroquine effectively inhibit the recently emerged novel coronavirus (2019-nCoV) in vitro. Cell Res 30: 269-271. Link: https://bit.ly/2VLPf8c

156. Sissoko D, Laouenan C, Folkesson E, M'Lebing AB, Beavogui $A H$, et al (2016) Experimental treatment with favipiravir for Ebola virus disease (the JIKI Trial): a historically controlled, single-arm proof-ofconcept trial in Guinea PLoS Med 13: e1002009. Link: https://bit.ly/3gtl8cl

157. Gilead gets EC conditional approval for remdesivir to treat Covid-19. Link: https://bit.ly/2ZEvwlF

158. Zhang C, Maruggi G, Shan H, Li J (2019) Advances in mRNA vaccines for infectious diseases. Front Immunol 10: 594. Link: https://bit.ly/3f3sTXt

159. Coutard B, Valle C, de Lamballerie X, Canard B, Seidah NG, et al. (2020) The spike glycoprotein of the new coronavirus 2019-nCoV contains a furin-like cleavage site absent in CoV of the same clade. Antiviral Res 176: 104742 Link: https://bit.ly/3gwkvjv

160. Link: http://www.cloverbiopharma.com/index.php?m=content\&c=index\&a $=$ lists \& catid $=42$.

161. Link: https://www.gsk.com/en-gb/media/pressreleases/cepi-and-gskannounce-collaboration-to-strengthenthe-global-effort-to-develop-avaccine-for-the-2019-ncov-virus/

162. Link: https://www.uq.edu.au/news/article/2020/02/ significantstep\%E2\%80\%99-covid-19-vaccine-quest.

163. Yang ZY, Kong WP, Huang Y, Roberts A, Murphy BR, et al. (2004) A DNA vaccine induces SARS coronavirus neutralization and protective immunity in mice. Nature 428: 561-564. Link: https://bit.ly/2Z36KTF

164. Sardesai NY, Weiner DB (2011) Electroporation delivery of DNA vaccines: prospects for success. Curr Opin Immunol 23: 421-429. Link: https://bit.ly/3iylgdJ

165. Link: http://ir.inovio.com/news-andmedia/news/press-releasedetails/2020/Inovio-Accelerates-Timeline-for-COVID-19-DNA-VaccineINO-4800/default.aspx.

166. Link: https://www.inovio.com/product-pipeline.

167. Link: https://www.inovio.com/technology\#dmab.

168. Link: https://www. modernatx.com/pipeline.

169. Pardi N, Hogan MJ, Porter FW, Weissman D (2018) mRNA vaccines - a new era in vaccinology. Nat Rev Drug Discov 17: 261-279. Link https://bit.ly/2ZFnDTs

170. Link: http://www.genexine.com/m21.php.

171. Loset GA, Roux KH, Zhu P, Michaelsen TE, Sandlie I (2004) Differential segmental flexibility and reach dictate the antigen binding mode of chimeric IgD and IgM: implications for the function of the B cell receptor. J Immunol 172: 2925-2934. Link: https://bit.ly/2VPyfhz

Citation: Poddar MK, Chakraborty A (2020) nCOVID-19: Its diagnosis, possible preventive measures, therapeutic interventions and management. Arch Community Med Public Health 6(2): 115-129. DOI: https://dx.doi.org/10.17352/2455-5479.000090 
172. Link: http://www.isrctn.com/ISRCTN89951424

173. Li X, Wang LW, Yang SN, Yang F, Xiang LK, et al. (2020) Clinical characteristics of 25 death cases infected with COVID-19 pneumonia: a retrospective review of medical records in a single medical center, Wuhan, China. Int J Infect Dis 94: 128-132. Link: https://bit.ly/2NV5IYO

174. Zhang B, Zhou X, Qiu Y, Feng F, Feng J, et al. (2020) Clinical characteristics of 82 death cases with COVID-19. medRxi Link: https://bit.ly/310Tgwo

175. Xie P, Ma W, Tang H, Liu D (2020) Severe COVID-19: A Review of Recent Progress With a Look Toward the Future. Front. Public Health 8: 189. Link: https://bit.ly/2018J4x

176. National Heart, Lung, and Blood Institute Acute Respiratory Distress Syndrome (ARDS) Clinical Trials Network, Wiedemann HP, Wheeler AP, Bernard GR, Thompson BT, et al. (2006) Comparison of two fluidmanagement strategies in acute lung injury. N Engl J Med 354: 2564-2575. Link: https://bit.ly/3e3zekv

177. Singer M, Deutschman CS, Seymour CW, Shankar-Hari M, Annane D, et al. (2016) The third international consensus definitions for sepsis and septic shock (Sepsis-3). JAMA 315: 801-810. Link: https://bit.ly/38txf7E

178. Panigrahy D, Gilligan MM, Huang S, et al. (2020) Inflammation resolution: a dual-pronged approach to averting cytokine storms in COVID-19? Cance Metastasis Rev 39: 337-340. Link: https://bit.ly/3gsKGrk

179. Brenchley JM, Douek DC (2012) Microbial translocation across the GI tract. Annu Rev Immunol 30: 149-173. Link: https://bit.ly/2VRwolV

180. 180.Ghosh SS, Wang J, Yannie PJ, Ghosh S (2020) Intestinal barrier dysfunction, LPS translocation, and disease development. J Endocrine Soc 4: bvz039. Link: https://bit.ly/2Z254d3

181. Gao QY, Chen YX, Fang JY (2020) 2019 Novel coronavirus infection and gastrointestinal tract. J Digestive Dis 21: 125-126. Link: https://bit.ly/2NX3h2m

182. Owler AA, Truwit JD, Hite RD, Morris PE, DeWilde C, et al. (2019) Effect of vitamin $C$ infusion on organ failure and biomarkers of inflammation and vascular injury in patients with sepsis andsevere acute respiratory failure: the CITRIS-ALI randomized clinical trial JAMA 322: 1261-1270. Link: https://bit.ly/3f30PI3

183. Carr AC (2020) A new clinical trial to test high-dose vitamin $C$ in patients with COVID19 Crit Care 24: 133 Link: https://bit.ly/2W6kVWf

184. Mair-Jenkins J, Saavedra-Campos M, Baillie JK, Cleary P, Khaw FM, et al. (2015) The effectiveness of convalescent plasma and hyperimmune immunoglobulin for the treatment of severe acute respiratory infections of viral etiology: a systematic review and exploratory meta-analysis. J Infect Dis 211: 80-90. Link: https://bit.ly/3f6uonC

185. Arabi YM, Hajeer AH, Luke T, Raviprakash K, Balkhy H, et al. (2016) Feasibility of using convalescent plasma immunotherapy for MERSCoV infection, Saudi Arabia. Emerg Infect Dis 22: 1554-1561. Link: https://bit.ly/2VOfMBZ

186. Shen C, Wang Z, Zhao F, Yang Y, Li J, et al. (2020) Treatment of 5 critically ill patients with COVID-19 with convalescent plasma. JAMA 323: 1582-1589. Link: https://bit.ly/2ZHwt36

187. Duan K, Liu B, Li C, Zhang H, Yu T, et al. (2020) Effectiveness of convalescent plasma therapy in severe COVID-19 patients. Proc Natl Acad Sci USA 117: 9490-9496. Link: https://bit.ly/2C4blvH

188. Wilson N, Kvalsvig A, Barnard LT, Baker MG (2020) Case-fatality risk estimates for COVID-19 calculated by using a lag time for fatality. Emerg Infect Ids 26: 1339-1441. Link: https://bit.ly/2C8gOli
189. Dent E, Morley JE, Cruz-Jentoft AJ, Woodhouse L, Rodriguez-Manas L, et al. (2019) Physical frailty: ICFSR International Clinical Practice Guidelines for identification and management. J Nutr Health Aging 23: 771-787. Link: https://bit.ly/2AyQErt

190. Rodgers M, Dalton J, Harden M, Street A, Parker G, et al. (2018) Integrated care to address the physical health needs of people with severe mental illness: a mapping review of the recent evidence on barriers, facilitators and evaluations. Int J Integr Care 18: 9. Link: https://bit.ly/2ZDuNre

191. Mao L, Wang M, Chen S, He Q, Chang J, et al. (2020) Neurologica Manifestations of Hospitalized Patients with COVID-19 in Wuhan, China: a retrospective case series study. Link: https://bit.ly/3e3SgH6

192. Sharma S, Sharma M, Singh G (2020) A chaotic and stressed environment for 2019-nCoV suspected, infected and other people in India: Fear of mass destruction and causality. Asian journal of psychiatry 51: 102049. Link: https://bit.ly/2C4b0sV

193. Qiu J, Shen B, Zhao M, Wang Z, Xie B, et al. (2020) A nationwide survey of psychological distress among Chinese people in the COVID-19 epidemic: implications and policy recommendations. Gen Psych 33: e100213. Link: https://bit.ly/3gtpFgc

194. Meng H, Xu Y, Dai J, Zhang Y, Liu B, et al. (2020) Analyze the psychological impact of COVID-19 among the elderly population in China and make corresponding suggestions. Psychiatry Res 289: 112983. Link: https://bit.ly/2ZGZ1cT

195. Brooks SK, Webster RK, Smith LE, Woodland L, Wessely S, et al. (2020) The psychological impact of quarantine and how to reduce it: rapid review of the evidence. Lancet 395: 912-920. Link: https://bit.ly/31MICY7

196. Gautam R, Sharma M (2020) 2019-nCoV Pandemic: A disruptive and stressful atmosphere for Indian academic fraternity. Brain, behavior and immunity S0889-1591(20)30506-7. Link: https://bit.ly/3f3pxUn

197. Link: https://www.who.int/emergencies/diseases/novelcoronavirus-2019/technical-guidance/infectionprevention-and-control.

198. Link: https://dailybrief.oxan.com/Analysis/ES251195/COVID-19-impactwill-be-worse-than-flu.

199. Ohannessian R, Duong TA, Odone A (2020) Global Telemedicine Implementation and Integration Within Health Systems to Fight the COVID-19 Pandemic: A Call to Action. JMIR public health and surveillance 6: e18810. Link: https://bit.ly/2DaRKuh

Discover a bigger Impact and Visibility of your article publication with Peertechz Publications

\section{Highlights}

* Signatory publisher of ORCID

* Signatory Publisher of DORA (San Francisco Declaration on Research Assessment)

* Articles archived in worlds' renowned service providers such as Portico, CNKI, AGRIS, TDNet, Base (Bielefeld University Library), CrossRef, Scilit, J-Gate etc.

* Journals indexed in ICMJE, SHERPA/ROMEO, Google Scholar etc.

* OAI-PMH (Open Archives Initiative Protocol for Metadata Harvesting)

* Dedicated Editorial Board for every journal

* Accurate and rapid peer-review process

* Increased citations of published articles through promotions

* Reduced timeline for article publication

Submit your articles and experience a new surge in publication services (https://www.peertechz.com/submission).

Peertechz journals wishes everlasting success in your every endeavours.

Copyright: @ 2020 Poddar MK, et al. This is an open-access article distributed under the terms of the Creative Commons Attribution License, which permits unrestricted use distribution, and reproduction in any medium, provided the original author and source are credited.

Citation: Poddar MK, Chakraborty A (2020) nCOVID-19: Its diagnosis, possible preventive measures, therapeutic interventions and management. Arch Community Med Public Health 6(2): 115-129. DOI: https://dx.doi.org/10.17352/2455-5479.000090 